\title{
TITLE:
}

\section{CORYCAEUS AND FARRANULA (COPEPODA, CYCLOPOIDA) IN HAWAIIAN WATERS}

$\operatorname{AUTHOR}(S)$ :

Motoda, Sigeru

\section{CITATION:}

Motoda, Sigeru. CORYCAEUS AND FARRANULA (COPEPODA, CYCLOPOIDA) IN HAWAIIAN WATERS. PUBLICATIONS OF THE SETO MARINE BIOLOGICAL LABORATORY 1963, 11(2): 209-262

\section{ISSUE DATE:}

1963-12-31

URL:

http://hdl.handle.net/2433/175343

RIGHT: 


\title{
CORYCAEUS AND FARRANULA (COPEPODA, CYCLOPOIDA) IN HAW AIIAN WATERS
}

\author{
Sigeru MOTODA \\ Faculty of Fisheries, Hokkaido University, \\ Hakodate, Hokkaido
}

With 1 Table and 29 Text-figures

The marine copopods of the genera Corycaeus and Farranula (=Corycella) occur in tropical and subtropical seas. However, some of them appear, and even reproduce, in certain high latitudes where warm ocean currents exist. M. DAHL's (1912) monograph on these groups has contributed much to the knowledge of their classification and geographical distribution. TANAKA (1957a) reported that twenty-four species belonging to these genera have been observed from the North Temperate Pacific, from as far as north as the Japanese coast where the Kuroshiwo Current and its tributaries prevail. These groups of copepods are easily recognized by the peculiar structure of their bodies and by their large paired eyes, and thus are very useful indicator forms of warm ocean currents. This study attempts to extend the present known distribution, and is based upon taxonomic work conducted on specimens collected in Hawaiian waters.

The materials consisted of plankton samples collected on Cruise 30 of the research vassel, Hugh M. Smith, of the U.S. Fish and Wildlife Service, at ten stations between Hawaii and about $50^{\circ} \mathrm{N}$ in August 1955 (McGARY et al., 1956); on Cruise 29 of the research vessel, John R. Manning, of the same agency, at six stations around Oahu Island, Hawaiian Archipelago, in January 1956; on Cruise 35 of the Hugh M. Smith at five stations around Oahu Island in August 1956: and on Cruise 34 of the research vessel, Makua, of the Division of Fish and Game, Board of Agriculture and Forestry, Hawaii, at two stations off the north-eastern coast of Oahu Island in December 1956 (Figs. 1, 2).

The plankton samples had been collected by oblique hauls (except those collected by the Makua in shallow waters by surface tows) with a 1-meter net equipped with flow-meter (KING and DEMOND, 1953). The sample volume varied considerably. In the case of large samples an appropriate aliquot $(1 / 2$,

Publ. Seto Mar. Biol. Lab., XI (2), 1963. (Article 15) 
$1 / 4,1 / 8$, or $1 / 16$ ) was examined. The number of animals of each species in 1000 cubic meters of water was determined.

The number of species and also number of animals in Corycaeus and Farranula gradually decreased from Hawaii to about $36^{\circ} \mathrm{N}$ and they were completely absent to the north of this latitude. This distribution is in general agreement with HIDA (1957) who stated that in the chaetognath and pteropod

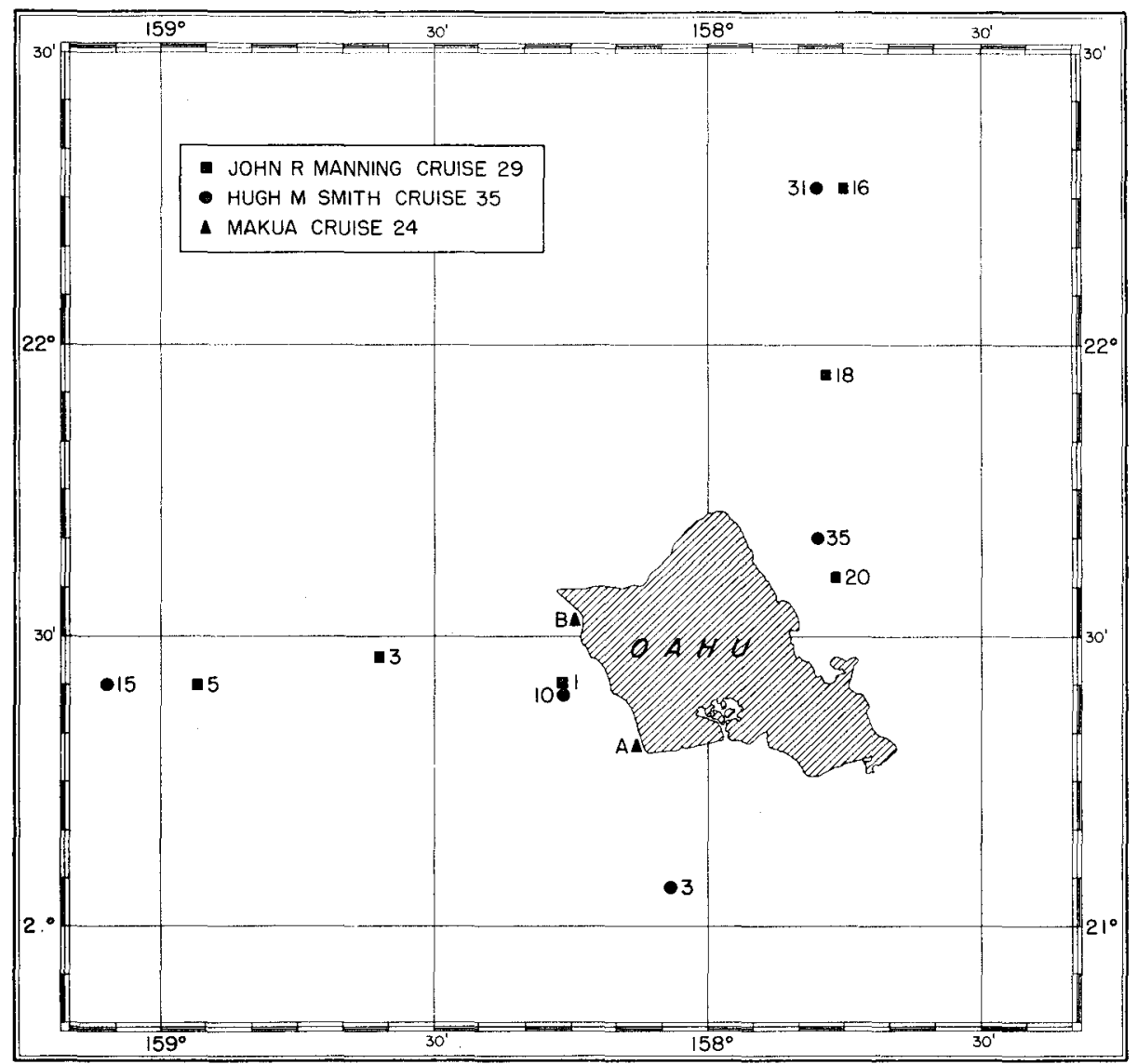

Fig. 1. Location of stations in Hawaiian waters from which samples were examined.

fauna the transition zone was observed between the subtropic and subarctic zones, roughly between $33^{\circ} \mathrm{N}$ and $45^{\circ} \mathrm{N}$ during fall and summer.

The following species were found in the samples examined:- (The complete record of the occurrence of each species at each station is given in Table 1.) 


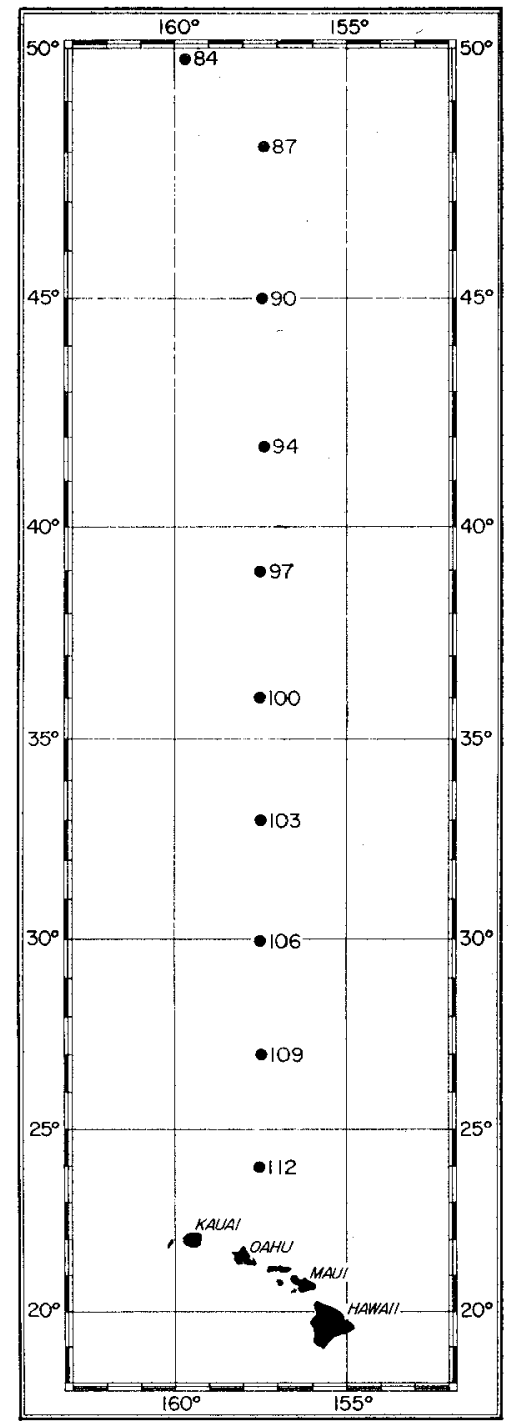

Fig. 2. Location of stations from Hawaii north to about $50^{\circ} \mathrm{N}$. from which samples were examined (Hugh M. Smith : Cruise-30).

1. Corycaeus (Corycaeus) speciosus DANA, male and female

2. Corycaeus (Corycaeus) crassiusculus DANA, male and female

3. Corycaeus (Corycaeus) vitreus DANA, male

4. Corycaeus (Monocorycaeus) robustus GiesBrechr, male and female

5. Corycaeus (Agetus) typicus KRöYER, male and female 
6. Corycaeus (Agetus) flaccus DANA, male and female

7. Corycaeus (Agetus) limbatus BRADy, male

8. Corycaeus (Urocorycaeus) longistylis DANA, male and female

9. Corycaeus (Urocorycaeus) lautus DANA, male and female

10. Corycaeus (Ditrichocorycaeus) asiaticus F. DAHL, male

11. Corycaeus (Onychocorycaeus) agilis DanA, male

12. Corycaeus (Onychocorycaeus) latus DANA, male

13. Corycaeus (Onychocorycaeus) catus F. DAHL, female

14. Farranula gibbula (GIEsBReCHT), male and female

15. Farranula carinata (GIESBRECHT), male and female

16. Farranula concinna (DANA), female

Several specimens assignable to genus Mimocorycella Rose 1929 were found in the samples examined during this study. There is a possibility that these are young forms of Corycaeus.

In this paper the references which contain at least some mention of the identification or a drawing, were listed in the synonymy list. However, in the distribution list, all available papers including those which only listed species' names, without mentioning any taxonomic characters, were cited. The length of body was expressed by measuring length from the tip of the forehead to the distal end of the furca when the body is stretched.

Most of specimens identified were put in separate vials with the species' name and other data on the label. They were deposited at the Biological Laboratory of the Bureau of Commercial Fisheries, U.S. Fish and Wildlife Service, in Honolulu, Hawaii. The permanent slides in Hoyer's medium of the appendages (1st antennae, 2nd antennae, maxillipeds, 1st swimming feet, 2nd swimming feet, 3rd swimming feet, 4th swimming feet and 5th feet) and also the abdomen with the furcae, were also deposited at that laboratory. Permanent preparations were made of the following species :-

Corycaeus (Corycaeus) speciosus, male (Box 1, No. 2)

Corycaeus (Corycaeus) crassiusculus, male (Box 1, No. 9, Box 2, No. 23)

Corycaeus (Corycaeus) vitreus, male (Box 1, Nos. 8, 14, 16)

Corycaeus (Monocorycaeus) robustus, female (Box 1, Nos. 3, 5, 6)

Corycaeus (Monocorycaeus) robustus, male (Box 1, No. 13)

Corycaeus (Agetus) typicus, female (Box 1, No. 18)

Corycaeus (Agetus) flaccus, female (Box 1, No. 17)

Corycaeus (Agetus) flaccus, male (Box 2, No. 28)

Corycaeus (Urocorycaeus) lautus, female (Box 1, Nos. 4, 7)

Corycaeus (Onychocorycaeus) agilis, famale (Box 1, Nos. 15, 19)

Corycaeus (Onychocorycaeus) latus, male (Box 2, No. 21)

Corycaeus (Onychocorycaeus) catus, female (Box 1, No. 12)

Corycaeus (Onychocorycaeus) sp. (Box 2, Nos. 26, 27) 
Farranula carinata, female (Box 2, No. 24)

Farranula carinata, male (Box 2, No. 25)

Farranula concinna, female, young (Box 2, Nos. 30, 31)

Corycaeus sp. young (Box 1, Nos. 1, 2, 10, 11, Box 2, Nos. 22, 29)

This work was performed by virtue of the existence of a grant for a Research Fellowship in Pacific Science provided by the University of Hawaii in 1957. The author wishes to express his sincere gratitude to the University of Hawaii for making this study possible. The author is also obliged to the Biological Laboratory, Bureau of Commercial Fisheries, in Honolulu, for their kindness, not only in providing excellent laboratory facilities during his stay in Hawaii in 1957-58 but also in placing the plankton samples at his disposal. $\mathrm{He}$ is also very grateful to the Woods Hole Oceanographic Institution, Woods Hole, Massachusetts, for the opportunity of visiting that institution to make the literature survey. He appreciates the arrangement of Seto Marine Biological Laboratory for publishing this paper.

\section{Genus Corycaeus DANA, 1845}

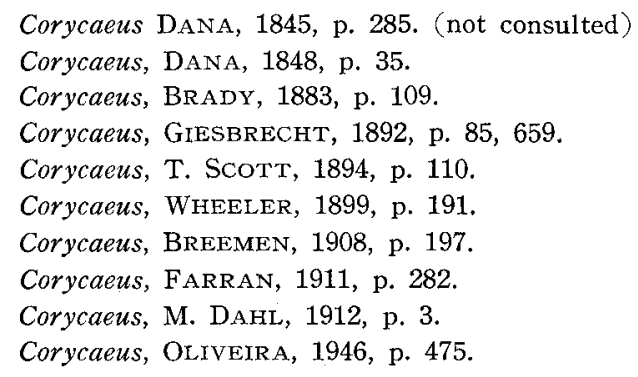

The genus Corycaeus was founded by Dana (1845) but the type of the genus was not indicated. Farran (1911) divided Dana's Corycaeus into two genera, Corycaeus and Corycella (=Farranula), and proposed that Corycaeus speciosus may be selected as the type for the genus Corycaeus.

\section{Corycaeus (Corycaeus) speciosus DaNA, 1848}

(Fig. 3)

Corycaeus speciosus DANA, 1848, p. 38.

Corycaeus varius (part), DANA, 1848, p. 36 .

Corycaeus remiger, DANA, 1848, p. 38.

Corycaeus longicaudatus, DANA, 1848, p. 39.

Corycaeus speciosus, DANA, 1852-55, p. 1211, pl. 85, figs. 1, 2-d.

Corycaeus varius (part), DANA, 1852-55, p. 1211, pl. 85, figs, 4, a-h.

Corycaeus remiger, DANA, 1852-55, p. 1221, pl. 86, figs. 2 , a, b.

Corycaeus longicaudis, DANA, 1852-55, p. 1226, pl. 86, figs. 9 , a'-c. 
Corycaeus speciosus, BRADY, 1883, p. 115, pl. 46, figs. 5, 6.

Corycaeus speciosus, Gresbrecht, 1892, p. 673, pl. 5, figs. 39, 40.

Corycaeus speciosus, F. DAHL, 1894, p. 73.

Corycaeus speciosus, BREEMEN, 1908, p. 199, figs. 212, a, b.

Corycaeus (Corycaeus) speciosus, M. DAHL, 1912, p. 13, pl. 1, figs. 1-13, pl. 2, figs. 1-4.

Corycaeus speciosus, Wilson, 1932, p. 358, figs. 216, a, b.

Corycaeus (s. str.) speciosus, Rose, 1933, p. 323, fig. 422.

Corycaeus speciosus, MORI, 1937, p. 133, pl. 72, figs. 9-15.

Corycaeus (Corycaeus) speciosus, Krishnaswamy, 1953, p. 70, figs. 12, 13.

Corycaeus (Corycaeus) speciosus, TANAKA, 1957a, p. 79, pl. 3, figs. 1-6.

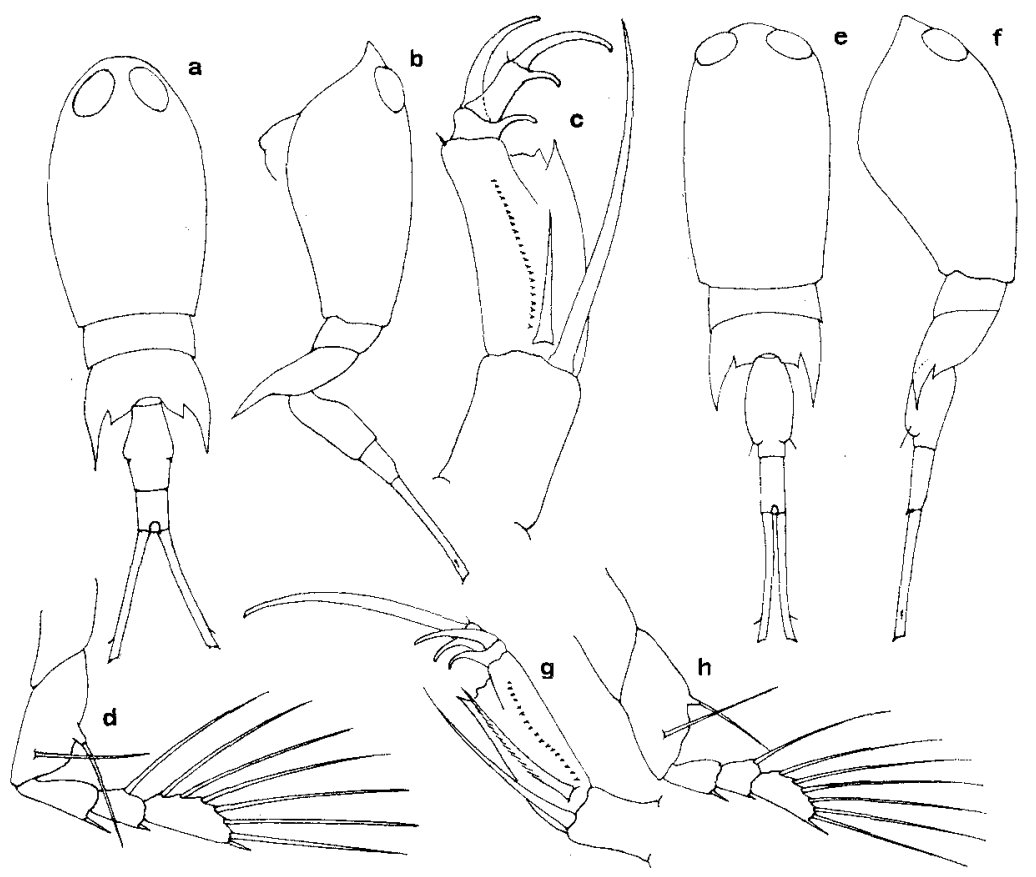

Fig. 3. Corycaeus (Corycaeus) speciosus

a. Female, dorsal, $\times 31$, b. Female, lateral, $\times 31$, c. Female, 2nd antenna, $\times 130, d$. Female, 4 th foot, $\times 85$, e. Male, dorsal, $\times 35, f$. Male, lateral, $\times 35$, g. Male, 2nd antenna, $\times 85, h$. Male, 4 th foot, $\times 130$

\section{Remarks :}

This species is one of the most common forms of Corycaeus in Hawaiian waters. Both females and males were nearly always prsent around Oahu Island. They were also distributed in the north in summer to about $33^{\circ} \mathrm{N}$ along $157^{\circ} 30^{\prime} \mathrm{W}$.

M. DAhL (1912) included Dana's (1848, 1852-55) Corycaeus varius (part), C. remiger and $C$. longicaudatus (longicaudis) in this species.

The female of $C$. speciosus is easily distinguished from other large-sized 
Corycaeus, in dorsal view, by its somewhat tapering, rounded forehead and by its long, divergent furcae, which are slightly longer than the combined length of the remainder of the abdomen. A bristle on the 1st segment of the 2nd antenna is about 2.8 times as long as a bristle on the 2 nd segment.

In the male the furcae are about 0.85 times as long as the remainder of the abdomen. The distal corner of inner margin of the 2 nd segment of the 2nd antenna is pointed.

CHIBA (1956) believed that this species breeds in Ariake Bay, southern Japan, in April and in the Bikini area in the tropical Pacific in May and June. Length: Female : 2.00-2.18 mm. (average of 29 specimens, $2.09 \mathrm{~mm}$.).

Male: $\quad 1.63-1.90 \mathrm{~mm}$. (average of 10 specimens, $1.76 \mathrm{~mm}$.).

Distribution: Tropical, Subtropical and North Temperate Atlantic:

DANA, $1848,1852-55,5^{\circ}-7^{\circ} \mathrm{N}, 21^{\circ}-22^{\circ} \mathrm{W}$ and also remiger, varius and longicaudatus (longicaudis).

BRADY, 1883.

Thompson, 1888, Madeira and Canary Is.

Giesbrecht, 1891, 1892.

T. Scott, 1894, Gulf of Guinea.

Thompson and A. Sсотт, 1903, English Channel to Gibraltar.

Breemen, 1908.

WOLFENDEN, 1911.

M. DAHL, 1912.

SARS, 1916.

FARRAN, 1929.

Rose, 1929, eastern and central North Temperate Atlantic.

WiLson, 1932a, off Woods Hole.

WiLson, 1932 b, Chesapeak Bay.

Klevenhusen, 1934, Tropical Atlantic.

WILSON, 1942.

Lysholm and NordgaARd, 1945, North Temperate Atlantic.

Oliveira, 1946, off Rio de Janeiro.

Moore, 1949 (as Corycella speciosus), Bermuda.

GrICE, 1960, Gulf of Mexico.

Mediterranean :

Thompson and A. Scotr, 1903.

Rose, 1934.

Arabian Sea :

Sewell, 1947.

Indo-Pacific :

Giesbrecht, 1891, 1892, Indian Ocean.

Thompson and A. Scott, 1903, Indian Ocean to Ceylon. 
Bedot, 1909, Malay Archipelago.

A. ScotT, 1909.

Farran, 1911, Christmas I. in Indian Ocean.

Mori, 1942, Palau Is., western Caroline.

WILSON, 1942.

Krishnaswamy, 1953, off Madras coast.

Tsuruta and Chiba, 1954, Mid-Pacific.

CHIBA et al. 1955. Bikini, Marshall Is.

Chiba and Tsuruta, 1955, west of Sunda Is.

Chiba et al. 1957, northern Indian Ocean.

Tanaka, 1957 a, off Japan.

Tsuruta et al. 1957, eastern Indian Ocean.

East China Sea :

Chiba, 1949.

Japan Sea :

Kokubo and SAto, Jusan Gata, Aomori.

MotodA et al. 1950, northern Japan Sea.

Chiba and Tsuruta, 1951, Tsushima Straits.

Motoda et al. 1951, northern Japan Sea.

Motoda et al. 1952, northern Japan Sea.

Anraku, 1953, Oshoro Bay.

Miyadi et al. 1954, Miho Bay and Nakaumi.

Tanaka, 1957b. off Yamaguchi, Shimane, Fukui, Toyama and Kyoto. South Pacific:

FARRAN, 1936, Great Barrier Reef.

Dakin and Colefax, 1940, off New South Wales, Australia.

North Pacific:

Giesbrecht, 1891, 1892.

Marukawa, 1921, off Japan.

MorI, 1937, off Japan.

Tokioka and Yamazi, 1950, Ago Bay, Mie.

Tokioka et al. 1951, Ago Bay, Mie.

Anraku, 1952, off northern Japan.

MaEKAw a et al. 1953, Suhonada.

Matsue and Komaki, 1953, Myojin-sho.

ANRAKU, 1954, off Japan.

MaEdA, 1956, Tsugaru Straits.

TANAKA, $1957 \mathrm{a}$, off Japan.

YAMAZI, 1958, Tanabe Bay, Wakayama. 


\section{Bering Sea :}

*WiLson, 1950.

Corycaeus (Corycaeus) speciosus DANA, yonng female

(Fig. 4)

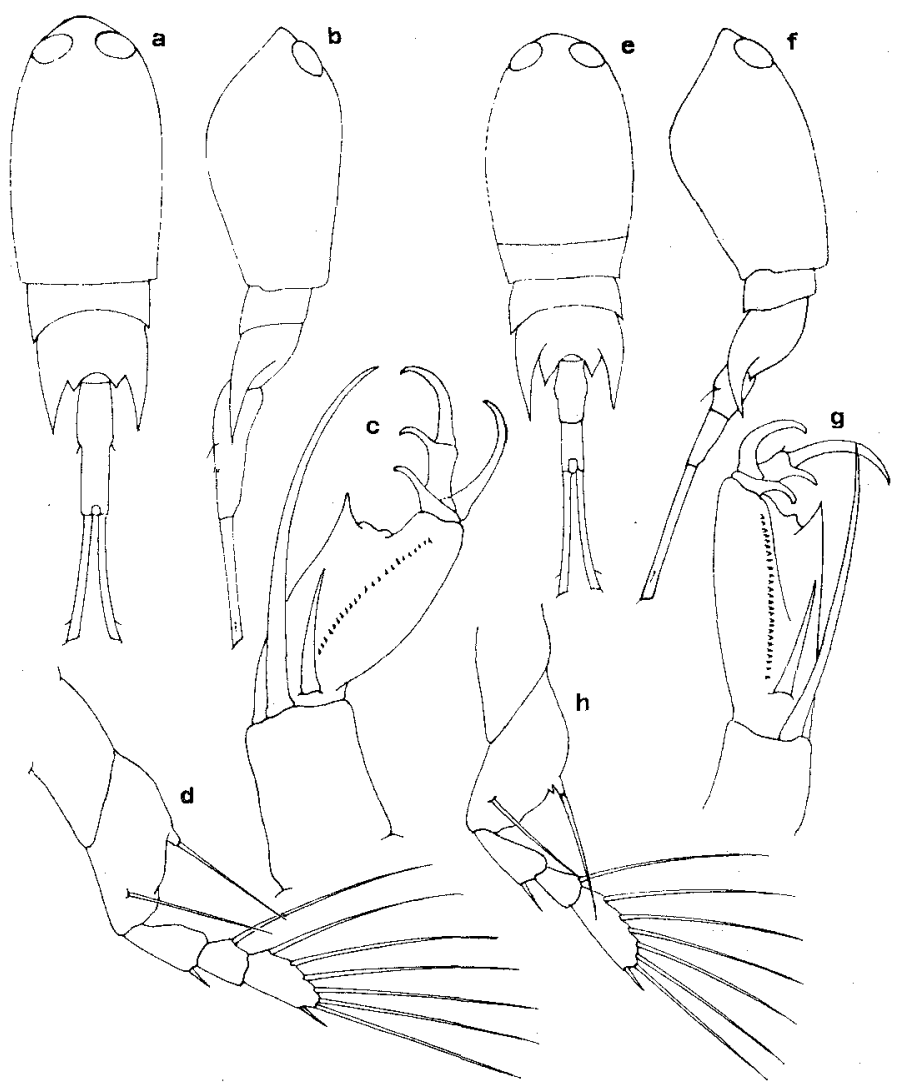

Fig. 4. Corycaeus (Corycaeus) speciosus, young female $a-d$. Specimen No. 1, 2- $h$. Specimen No. 2 ; a. Dorsal, $\times 31$, $b$. Lateral, $\times 31, c$. 2nd antenna, $\times 130, d .4$ th foot, $\times 130, e$. Dorsal, $\times 31, f$. Lateral, $\times 31, g$. 2nd anntenna, $\times 130, h .4$ th foot, $\times 130$

Two specimens which are presumably young females of Corycaeus (Corycaeus) speciosus were found, one (specimen, No. 1) at JRM-29, St. 20 and another

* Wilson (1950) reported quite a number of species of Corycaeus from the Bering Sea. Since Corycaeus is a warm water copepod, these are the first records for a cold water region. However, it seems that WILSON's samples may possibly have been mislabelled. 
(specimen, No. 2) at HMS-35, St. 35. The total length, including furcae, is $2.07 \mathrm{~mm}$. and $1.87 \mathrm{~mm}$. respectively. The 2 nd antennae and 4 th feet resemble those of adult female, but abdomen is one-segmented (in the specimen, No. 1) and the furcae are not as divergent as in the adult. The spines (homologous to the 6th feet) on the genital segment are located ventrally, indicating that these specimens are in young stage.

\section{Corycaeus (Corycaeus) crassiusculus DANA, 1848}

(Fig. 5)

Corycaeus crassiusculus DANA, 1848, p. 36 .

Corycaeus venustus, DANA, 1848, p. 38.

Corycaeus crassiusculus, DANA, 1852-55, p. 1214, p1. 85, figs. 7, a, b.

Corycaeus venustus, DANA, $1852-55$, p. 1222 , pl. 86 , figs. 4 , a, $\mathrm{a}^{\prime}-\mathrm{d}$.

Corycaeus danae, GIESBRECHT, 1891, p. 480.

Corycaeus danae, GIESBRECHT, 1892, p. 660, pl. 51, figs. 59, 60 .

Corycaeus crassiusculus, F. DAHL, 1894, p. 73.

Corycaeus (Corycaeus) crassiusculus, M. DAHL, 1912, p. 21, pl. 3, figs. 1-7.

Corycaeus crassiusculus, FARRAN, 1929, p. 291, figs. 36, a, b.

Corycaeus crassiusculus, FARRAN, 1936, p. 134, figs. 8, c. d.

Corycaeus crassiusculus, MORI, 1937, p. 133, pl. 75, figs. 1-5.

Corycaeus (Corycaeus) crassiusculus, SEwELL, 1947, p. 272, figs. 69, A-H.

Corycaeus (Corycaeus) crassiusculus, TANAKA, 1957a, p. 80, pl. 3, figs. 12-15.

Remarks :

This species was common around Oahu Island, and it was distributed to the north to about $27^{\circ} \mathrm{N}$. It seemed to increase in numbers especially in the numbers of males, in winter.

DANA's $(1848,1952-55)$ descriptions of $C$. crassiusculus were based exclusively on male specimens. However, the female of C. venustus described in the same papers was later identified by M. DAHL (1912) as the female of C. crassiusculus. The name $C$. venustus was therefore dropped.

In the female, the anterior body is $1.6-1.9$ times as long as the abdomen. The furcae are divergent as in female C. speciosus, but are shorter. They are 0.5-0.8 times as long as the remainder of the abdomen. M. DAHL (1912, p. 22) mentioned that the length of the furca in $C$. crassiusculus may vary with individuals, and $S_{E W E L L}$ (1947) obtained the values of 0.5-0.6 for the proportional length of furca to the remainder of the abdomen. CHIBA (1954) reported on the deformity of the furca in this species. The genital segment overlaps the anal segment at dorsal margin, unlike that of female $C$. speciosus. According to FARRAN (1929, p. 292, figs. 35, 36), the females of this species from New Zealand waters do not have such a slender abdomen as those figured by Giesbrecht (1892) or M. DAhL (1912), and they closely resemble the female of C. clausi. M. DAHL (1912, p. 22) described the anal segment of the female $C$. 
(C.) crassiusculus as tapering posteriorly and being 1.5 times as long as the breadth at its distal margin, while being almost cylindrical and hardly longer than its breadth in the female of $C$. (C.) clausi (p. 19). In the Hawaiian specimens the ratio of length to breadth of the anal segment (distal margin) varied with specimens within the range of 1.1-1.8. These specimens were however identified as the female of $C$. (C.) crassiusculus, largely because the genital segment overlaps the anal segment at the dorsal margin. Although there is a mention by M. DAHL (1912) of such an overlap of the genital segment on the anal

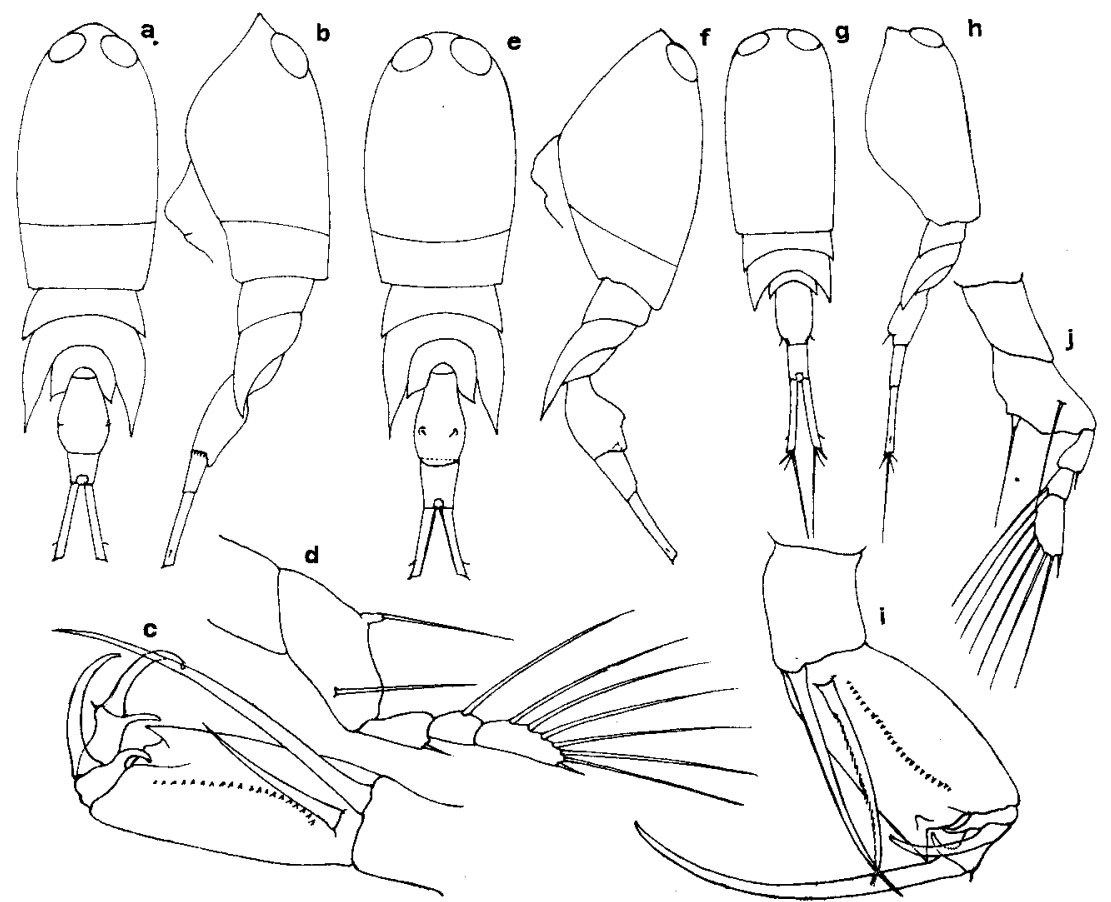

Fig. 5. Corycaeus (Corycaeus) crassiusculus

$a-d$. Female specimen No. $1, e-f$. Female specimen No. 2 ; $a$. Female, dorsal, $\times 31$,

$b$. Female, lateral, $\times 31, c$. Female, 2nd antenna, $\times 130, d$. Female, 4th foot, $\times 130$

$e$. Female, dorsal, $\times 31, f$. Female, lateral, $\times 31, g$. Male, dorsal, $\times 31, h$. Male,

lateral, $\times 31, i$. Male, 2nd antenna, $\times 130, j$. Male, 4 th foot, $\times 130$

segment in the female of $C$. (C.) clausi (p. 12), his key and figure (pl. 2, fig. 6) do not show it.

Among the specimens in the Hawaiian samples, a few females were infected with ectoparasitic algae on and around the dorsal surface of last thoracic segment. These parasitic algae roughly resemble those reported as Amophora found on C. speciosus and C. gracilis by KLEVENHUSEN (1933). 
In the male, the length of the genital segment nearly equals the length of the furca. The anal segment, in dorsal view, is about twice as long as its width.

This species was reported to breed in the sea adjacent to Sunda Chain in the Indian Ocean in December and January (CHIBA, 1956).

Length: Females : $1.68-2.00 \mathrm{~mm}$. (average of 36 specimens, $1.81 \mathrm{~mm}$.).

Male: $\quad 1.42-1.75 \mathrm{~mm}$. (average of 15 specimens, $1.55 \mathrm{~mm}$.).

Distribution :

Atlantic:

Thompson, 1888, as venustus, Madeira and Canary Is.

Giesbrecht, 1891, as danae.

WILSON, 1942.

Arabian Sea :

Sewell, 1947.

Indo-Pacific :

Dana, 1848, 1852-55, Sulu Sea, and as venustus, Kingsmill.

GIESBRECHT, 1891, 1892, as danae.

M. DAHL, 1912.

Mori, 1942, Palau Is. western Caroline.

WILSON, 1942.

Wilson, 1950.

Tsuruta and Chiba, 1954, Mid-Pacific.

ChiBA et al. 1955, Bikini, Marshall Is.

Chiba and Tsuruta, 1955, west of Sunda Is.

Chiba et al. 1957, northern Indian Ocean.

Tsuruta et al. 1957, eastern Indian Ocean.

Japan Sea :

YAmazi, 1952 b, Nanao Bay, Noto Peninsula.

TANAKA, 1957b, off Yamaguchi, Kyoto.

South Pacific:

FARRAN, 1929.

FARran, 1936, Great Barrier Reef.

Dakin and Colefax, 1940, off New South Wales, Australia.

North Pacific:

MORI, 1937, off Japan.

YAMAZI, 1952a, Hiroshima Bay, Inland Sea of Japan.

YAMAZI, 1958, Tanabe Bay, Wakayama. 


\section{Corycaeus (Corycaeus) vitreus DANA, 1848}

(Fig. 6)

?Corycaeus vitreus DANA, 1848, p. 37.

?Corycaeus vitreus, DANA, 1852-55, p. 1216, pl. 85, figs. 9, a-d.

Corycaeus vitreus, F. DAHL, 1894, p. 73.

Corycaeus (Corycaeus) vitreus, M. DAHL, 1912, p. 25, pl. 3, figs. 8-13.

Corycaeus vitreus, FARRAN, 1936, p. 134, figs. 28, a-d.

Corycaeus (Corycaeus) vitreus, DAKIN and ColEFAX, 1940, p. 111, figs. 196, a. b.

Corycaeus (Corycaeus) viretus, TANAKA, 1957a, p. 81, pl. 4, figs. 1-4.

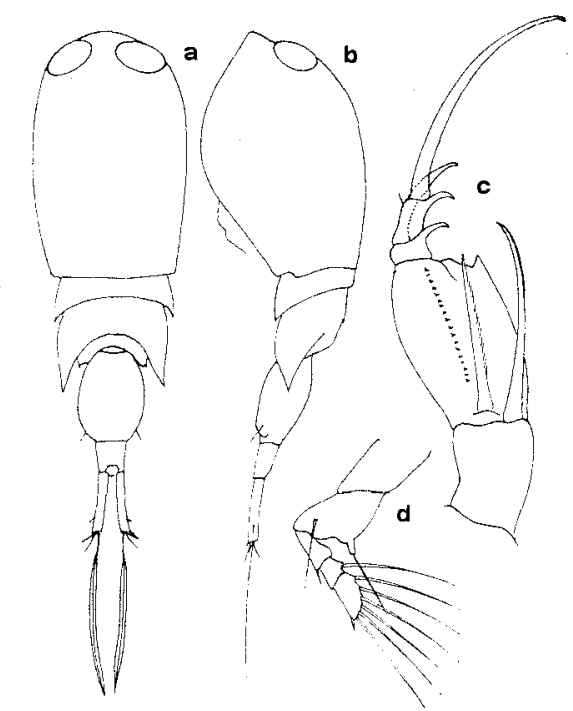

Fig. 6. Corycaeus (Corycaeus) vitreus

a. Male, dorsal, $\times 31, b$. Male, lateral, $\times 31$, c. Male, 2nd antenna, $\times 85, d$. Male, 4 th foot, $\times 85$

\section{Remarks:}

Only male specimens were found. They occurred both in winter and summer, but in winter, they were found only on the leeward side of Oahu Island. The northerly distribution ranged to around $27^{\circ} \mathrm{N}$.

DANA's (1848, 1852-55) original description and figures for the male of this species are not distinct. M. DAHL (1912) defined the characters of the male according to the description given by F. DAHL (1894).

The body is rather robust. The genital segment is nearly as long as the furca. FARRAN (1936, p. 134, 135) mentioned that the male of this species differs from males of $C$. crassiusculus and $C$. clausi by its relatively short head which is very broad in front and tapers posteriorly, by its short anal segment, 
and by the fine transparent edge on the longest furcal setae. The same author (1929) collected a specimen which was supposedly C. vitreus from New Zealand waters, but reported it as a female of C. crassiusculus. He later (1936, p. 134, 135, figs. 28, c) described the female of $C$. vitreus for the first time on a specimen from the Great Barrier Reef. The same author (1936) reported that the female of $C$. vitreus is more robust than the female of $C$. crassiusculus; that the abdomen, in dorsal view, is shorter and broader, though scarcely differing from $C$. crassiusculus in lateral view; and that furca is noticeably broader and more tapered.

Length: Male : $1.65-1.85 \mathrm{~mm}$ (average of 21 specimens, $1.72 \mathrm{~mm}$ ).

Distribution:

Indo-Pacific :

DANA, $1848,1852-55,18^{\circ} \mathrm{S}, 124^{\circ} 30^{\prime} \mathrm{W}$.

Wilson, 1950.

Japan Sea :

TANAKA, 1957b, Yamaguchi and Kyoto.

South Pacific:

FARRAN, 1936, Great Barrier Reef.

Dakin and Colefax, 1940, off New South Wales, Australia.

North Pacific:

TANAKa, 1957a, off Japan.

4. Corycaeus (Monocorycaeus) robustus GIESBRECHT, 1891

(Fig. 7)

Corycaeus venustus (part), BRADY, 1883, p. 115, pl. 54, figs. 8-10.

Corycaeus robustus GIEsBRECHT, 1891, p. 480.

Corycaeus robustus, GIESBREcHT, 1892, p. 660, pl. 51, figs. 38, 42.

Corycaeus robustus, F. DAHL, 1894, p. 69.

Corycaeus robustus, A. SCOTT, 1909, p. 251.

Corycaeus (Monocorycaeus) robustus, M. DAHL, 1912, p. 27, pl. 4, figs. 1-8.

Corycaeus robustus, WILsON, 1942, p. 182.

Corycaeus (Monocorycaeus) robustus, TANAKA, 1957a, p. 81, pl. 4, figs. 5-8.

Remarks :

This species occurred more commonly in summer than in winter and were chiefly females. The males were found in small numbers in summer.

The subgenus Monocorycaeus includes only one species. Since Brady's (1883) description of the female of $C$. venustus did not include any character of specific value, this species has been placed in Giesbrecht's $(1891,1892)$ robustus (ref. to FARRAN, 1911, p. 289).

In both sexes, the body is very stout, with robust genital segment and 
very short anal segment. The furcae are divergent. The terminal claw of the 2nd antenna is not elongated.

Length: Female : 2.10-2.40 mm. (average of 19 specimens, $2.24 \mathrm{~mm}$.).

Male: $\quad 1.83-1.95 \mathrm{~mm}$. (average of 3 specimens, $1.87 \mathrm{~mm}$.).

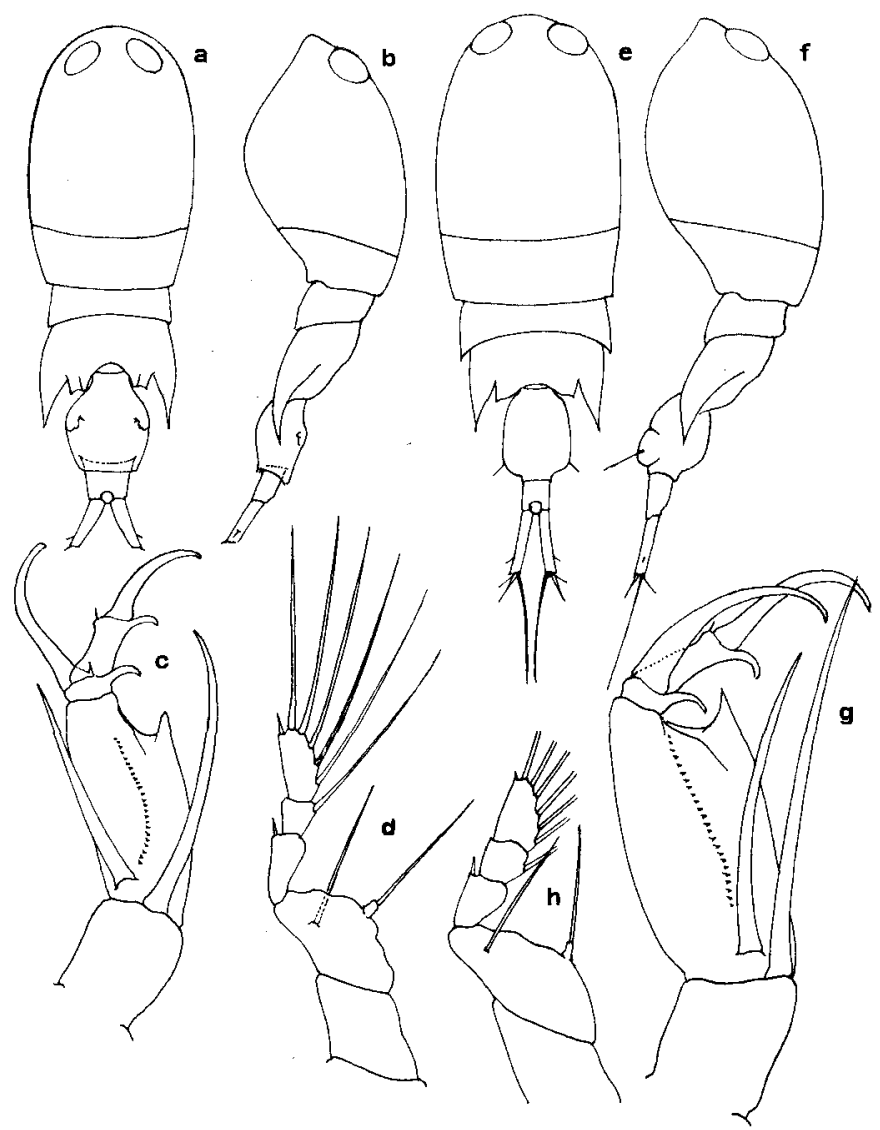

Fig. 7. Corycaeus (Monocorycaeus) robustus

$a$. Female, dorsal, $\times 24, b$. Female, lateral, $\times 24$, c. Female, 2nd antenna, $\times 85, d$. Female, 4th foot, $\times 85$, e. Male, dorsal, $\times 31$, $f$. Male, lateral, $\times 31, g$. Male, 2nd antenna, $\times 140, h$. Male, 4th foot, $\times 130$

\section{Distribution:}

\section{Atlantic :}

BRADY, 1883, as venustus.

Giesbrecht, $1891,1892,7^{\circ} \mathrm{S}, 90^{\circ} \mathrm{W} ; 20^{\circ} \mathrm{N}, 17^{\circ} \mathrm{W}$.

WOLFENDEN, 1911.

Wilson, 1932 b, Chesapeak Bay. 
Indo-Pacific :

Brady, 1883, as venustus.

Giesbrechi $, 1891,1892,5^{\circ} \mathrm{N}, 115^{\circ} \mathrm{W} ; 9^{\circ} \mathrm{N}, 119^{\circ} \mathrm{W}$.

Thомpson and A. Scotт, 1903, northern Indian Ocean.

A. ScotT, 1909.

Farran, 1911, Christmas I. in Indian Ocean.

M. DAHL, 1912.

WILSON, 1942.

WILSON, 1950.

South Pacific:

FarRan, 1936, Great Barrier Reef.

North Pacific:

TANAKA, 1957a, off Japan.

5. Corycaeus (Agetus) typicus KRÖYER, 1849

(Fig. 8)

Agetus typicus KRÖYER, 1849, Naturhist. Tiddsskr. Köbenhaven, Ser. 2, Vol. 2, p. 603, pl. 6, figs. 27-29. (not consulted.).

Corycaeus elongatus, Claus, 1863, Freilebenden Copepoden mit besonderer Berücksichtigung der Fauna Deutschlands, der Nordsee und des Mittelmeeres. Leipzig, Verh. W. Engelmann, p. 157 , pl. 24 , figs. 3 , 4. (not consulted.).

Corycaeus alatus, GIESBRECHT, 1891, p. 480.

Corycaeus elongatus, GIESBRECHT, 1891, p. 480.

Corycaeus alatus, GIESBRECHT, 1892, p. 674, pl. 51, figs. 8, 9.

Corycaeus elongatus, GIESBRECHT, 1892, p. 674, pl. 51, fig. 35.

Corycaeus (Agetus) typicus, M. DAHL, 1912, p. 31, pl. 4, figs. 9-14, pl. 5, figs. 1-3.

Corycaeus (Agetus) typicus, Rose, 1933, p. 328, fig. 425.

Corycaeus (Agetus) typicus, TANAKA, 1957a, p. 81, pl. 4, figs. 9-15.

Remarks:

This species occurred only on the windward side of Oahu Island in winter, and on both sides of the island in summer. The males were encountered only in summer.

M. Dahl (1912) synonymized Claus' (1863) C. elongatus and Giesbrecht's (1891, 1892) C. elongatus and C. alatus with KRöyer's Agetus typicus.

The famale has a one-segmented abdomen. In dorsal view, it is swollen only in the mid-portion. In lateral view, it is prominently swollen dorsally in the mid-portion; tapers posteriorly with an irregular contour. Furcae are parallel and separated throughout their entire length. The female of this species is easily recognized by its 4 th thoracic segment, which, in lateral view, protrudes posteriorly and form a right angle at the dorsal corner. In addition, a row of teeth on the outer margin of the 2nd segment of the 2nd antenna is characteristic of this species. However, in some of the Hawaiian specimens, 
which are undoubtedly $C$. (A.) typicus judging by the peculiar 4 th thoracic segment, the teeth on the 2 nd segment of the 2 nd antenna are indistinct. The long slender bristle on the 1st and 2nd segments of the 2nd antenna are nearly equal in length.

In the male of the subgenus Agetus, the inner margin of the 2nd segment

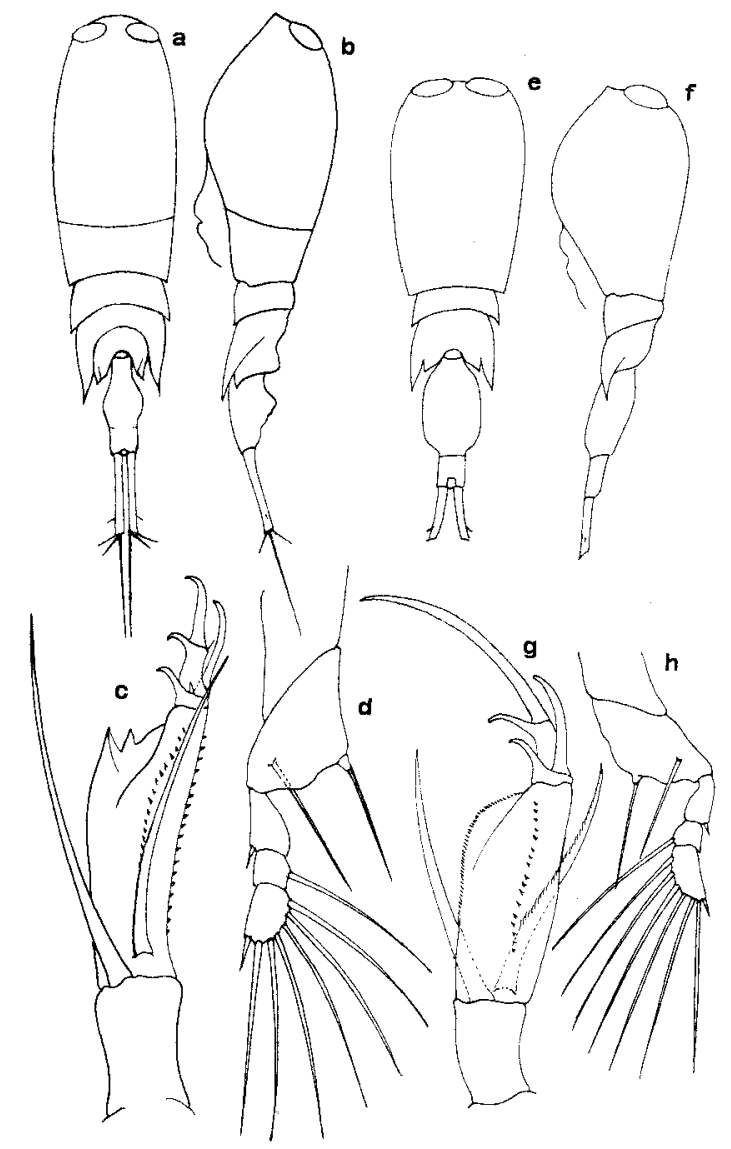

Fig. 8. Corycaeus (Agetus) typicus

a. Female, dorsal, $\times 31, b$. Female, lateral, $\times 31$,

$c$. Female, 2nd antenna, $\times 130, d$. Female, 4th foot,

$\times 130$, e. Male, dorsal, $\times 31, f$. Male, lateral, $\times 31$,

$g$. Male, 2nd antenna, $\times 130$, h. Male, 4th foot, $\times 130$

of the 2nd antenna is rounded at the distal corner, and not produced into a spine, and the margin is furnished with fine teeth. In the male of $C$. $(A$.) typicus the genital segment is shorter than the combined length of the anal segment and the furca. The anal segment, in dorsal view, is almost square. Length: Female : $1.57-1.80 \mathrm{~mm}$ (average of 25 specimens, $1.74 \mathrm{~mm}$ ). 
Male: $\quad 1.55-1.60 \mathrm{~mm}$ (average of 4 specimens, $1.57 \mathrm{~mm}$ ).

\section{Distribution:}

Tropical, Subtropical and North Temperate Atlantic:

M. DAHL, 1912.

Rose, 1929.

Klevenhusen, 1934, Tropical Atlantic.

WILson, 1942.

Mediterranean :

M. DAHL, 1912.

Rose, 1929.

Rose, 1934.

Massuti, 1948, Gulf of Naples.

South Atlantic:

GIESBREChT, 1891,1892 , as elongatus, $25^{\circ} \mathrm{S}, 44^{\circ} \mathrm{W}$.

FARran, 1929.

KLevenhusen, 1934.

Indo-Pacific :

Giesbrecht, 1891,1892 , as alatus, $0^{\circ}, 180^{\circ} ; 15^{\circ} \mathrm{N}, 138^{\circ} \mathrm{W} ; 16^{\circ} \mathrm{N}, 163^{\circ} \mathrm{E}$.

FARRAN, 1911, as alatus, Christmas I. in Indian Ocean.

M. DAHL, 1912.

WILSON, 1942.

WILson, 1950.

South Pacific:

FARRAN, 1936, Great Barrier Reef.

North Pacific:

TANAKA, 1957 a, off Japan.

Bering Sea :

WiLson, $1950(?)$

\section{Corycaeus (Agetus) flaccus GIESBRECHT, 1891}

(Fig. 9)

Corycaeus flaccus GIESBRECHT, 1891, p. 480.

Corycaeus flaccus, GiesBRECHT, 1892, p. 659, pl. 51, figs. 10, 11.

Corycaeus flaccus, F. DAHL, 1894, p. 70.

Corycaeus (Agetus) flaccus, M. DAHL, 1912, p. 35, pl. 5, figs. 4-11.

Corycaeus (Agetus) flaccus, Rose, 1933, p. 329, fig. 426.

Corycaeus flaccus, MoRI, 1937, p. 135, pl. 73, figs. 9-15.

Corycaeus flaccus, Wilson, 1942, p. 181, fig. 50.

Corycaeus (Agetus) flaccus, TANAKA, 1957a, p. 82, pl. 5, figs. 1-7.

\section{Remarks :}

This species was more commonly distributed in Hawaiian waters than 
C. (A.) typicus. Both females and males seemed to be relatively more abundant in summer than in winter.

Differing from the female of a preceding species, $C$. (A.) typicus, the female of this species has a small, rounded tubercle, which is easily seen in lateral

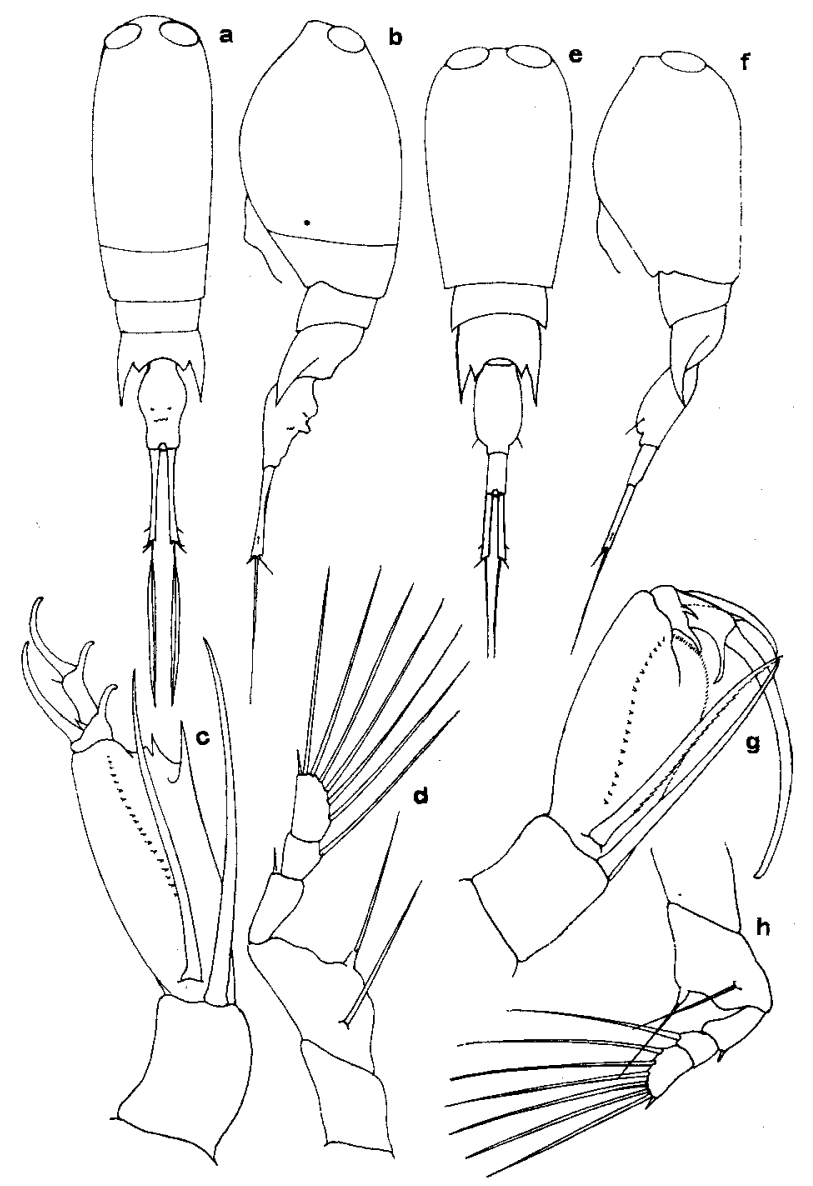

Fig. 9. Corycaeus (Agetus) flaccus

a. Female, dorsal, $\times 31, b$. Female, lateral, $\times 31, c$. Female, 2nd antenna. $\times 130, d$. Female, 4th foot, $\times 150$, e. Male, dorsal, $\times 35, f$. Male, lateral, $\times 35, g$. Male, 2nd antenna, $\times 150, h$. Male, 4 th foot, $\times 150$

view, on the dorsal surface of the genital segment. The furca is longer than the rest of the abdomen. The outer margin of the 2nd segment of the 2nd antenna is not provided with teeth, thus also differing from $C$. (A.) typicus.

The male is more slender than the male of $C$. (A.) typicus. The genital 
segment is shorter than the combined length of the anal segment and the furca. The anal segment is much longer than its width.

Breeding in this species was observed in the Bikini area, tropical Pacific, from May to June (CHIBA, 1956).

Length: Female : $1.60-1.75 \mathrm{~mm}$. (average of 20 specimens, $1.67 \mathrm{~mm}$.)

Male: $\quad 1.40-1.57 \mathrm{~mm}$. (average of 18 specimens, $1.50 \mathrm{~mm}$.)

\section{Distribution:}

Tropical, Subtropical and Temperate North Atlantic:

Thomson and A. Scotr, 1903, eastern North Atlantic.

Wolfenden, 1911.

M. DAHL, 1912.

SARS, 1916.

Candeias, 1926, off Portugal.

FARRAN, 1929.

Rose, 1929.

Klevenhusen, 1934, Tropical Atlantic.

Lysholm and NordgaArd, 1945, North Temperate Atlantic.

Mediterranean :

Thompson and A. Scott, 1903.

Rose, 1929.

Rose, 1934.

Massuti, 1948, Gulf of Naples.

Garibbean Sea :

WILSON, 1942.

Indo-Pacific :

Giesbrecht, $1891,1892,0^{\circ}, 108^{\circ} \mathrm{W} ; 1^{\circ} \mathrm{N}, 109^{\circ} \mathrm{W} ; 16^{\circ} \mathrm{N}, 169^{\circ} \mathrm{E}$.

Thomson and A. Scott, 1903, Indian Ocean to Ceylon.

A. Scott, 1909.

Farran, 1911, Christmas I. in Indian Ocean.

M. DAHL, 1912.

MorI, 1942, Palau Is., western Caroline.

WILson, 1942.

WILSON, 1950.

Tsuruta and Chiba, 1954, Mid-Pacific.

Chiba and Tsuruta, 1955, West of Sunda Is.

ChiBA et al. 1955, Bikini, Marshall Is.

ChibA et al. 1957. northern Indian Ocean.

Tsuruta et al. 1957, eastern Indian Ocean.

Japan Sea :

Shimomura, 1954, Central Japan Sea.

YAMAZI, 1954, Obama Bay, Fukui. 
TANAKA, 1957b, off Fukui and Kyoto.

South Pacific:

FARRAN, 1936, Great Barrier Reef.

North Pacific :

MORI, 1937, off Japan.

AnRaKU, 1952, off northern Japan.

TANAKA, 1957a, off Japan.

YAMAZI, 1958, Tanabe Bay, Wakayama.

OLson (MS.), west coast of North America.

Bering Sea :

WiLson, 1950 ?

7. Corycaeus (Agetus) limbatus BRADY, 1883

(Fig. 10)

Corycaeus limbatus (part) BRADY, 1883, p. 114, pl. 49, figs. 18-22.

Corycaeus elongatus (part), CIESBRECHT, 1891, p. 480.

Corycaeus elongatus (part), GIESBRECHT, 1892, p. 673, pl. 51, fig. 35.

Corycaeus limbatus, F. DAHL, 1894, p. 70.

Corycaeus (Agetus) limbatus, M. DAHL, 1912, p. 38, pl. 5, figs. 12-14, pl. 6, figs. 1-5.

Corycaeus (Agetus) limbatus, Rose, 1933, p. 328, fig. 424.

Corycaeus limbatus, W.LSON, 1942, p. 181.

Corycaeus (Agetus) limbatus, TANAKA, 1957a, p. 83, pl. 5, figs. 8-12.

\section{Remarks:}

Males only of this species were taken at one station on the windward side of Oahu Island in winter.

The body is broader than in other species belonging to this subgenus and the eyes are situated very close together.

The body lengths of the male as reported by previous workers were: $1.55 \mathrm{~mm}$ (BRADY, 1883) ; 1.3-1.4 mm (GIESBRECHT, 1892, as elongatus) ; 1.15-1.16 mm (? Dahl, 1912); $1.2 \mathrm{~mm}$ (Rose, 1933); and $1.22 \mathrm{~mm}$ (Tanaka, 1957a). The specimens in Hawaiian waters are larger than those specimens which were reported from other regions, except the Challenger specimens (BRADY, 1883).

Length: Male : $1.28-1.67 \mathrm{~mm}$ (average of 8 specimens, $1.46 \mathrm{~mm}$ ).

Distribution:

Tropical and Subtropical Atlantic:

BRADY, 1883.

Thompson, 1883, Madeira and Canary Is.

Giesbrecht, 1891,1892 , as elongatus, $25^{\circ} \mathrm{S}, 44^{\circ} \mathrm{W}$.

M. DAHL, 1912.

Rose, 1929.

Klevenhusen, 1934, Tropical Atlantic. 
WILson, 1942.

Mediterranean :

M. DAHL, 1912.

Rose, 1929.

Massuti, 1948, Gulf of Naples.

South Atlantic:

FARRAN, 1929.

Klevenhusen, 1934.

Indo-Pacific :

A. Sсотт, 1909.

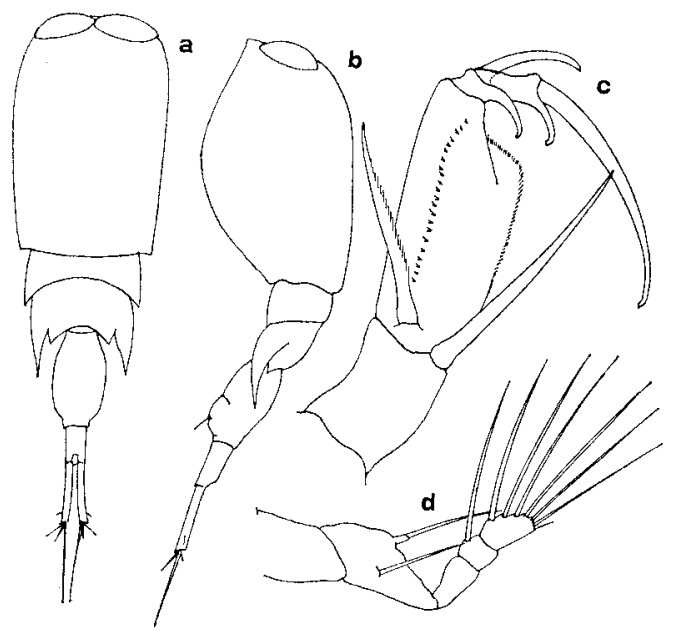

Fig. 10. Corycaeus (Agetus) limbatus

$a$. Male, dorsal, $\times 35, b$. Male, lateral, $\times 35$,

$c$. Male, 2nd antenna, $\times 130, d$. Male, 4th foot, $\times 150$

FARRAN, 1911, as elongatus, Christmas I. in Indian Ocean.

M. DAHL, 1912.

Wilson, 1942.

WILson, 1950.

South Pacific:

FARRAN, 1936, Great Barrier Reef.

North Pacific:

TANAKA, 1957a, off Japan.

Olson (MS.) off west coast of North America.

$$
-60-
$$




\section{Corycaeus (Urocorycaeus) longistylis DANA, 1848}

(Fig. 11)

Corycaeus longistylis DANA, 1848, p. 36

Corycaeus longistylis, DANA, 1852-55, p. 1212, pl. 85, figs. 5, a-d.

Corycaeus varius (part), BRADY, 1883, p. 111, pl. 52, figs. 1-14.

Corycaeus longistylis, GiesBrecht, 1891, p. 480.

Corycaeus longistylis, GiesBRECHT, 1892, p. 674, pl. 51, figs. 36, 37.

Corycaeus longistylis, F. DAHL, 1894, p. 70.

Corycaeus longistylis, A. ScotT, 1909, p. 249.

Corycaeus (Urocorycaeus) longistylis, M. DAHL, 1912, p. 42, pl. 6, figs. 6-13, pl. 7, figs. 1-3.

Corycaeus longistylis, MORI, 1937, p. 134, pl. 73, figs. 3-8.

Corycaeus (Urocorycaeus) longistylis, Dakin and Colefax, 1940, p. 113, figs. 188, a-d.

Corycaeus (Urocorycaeus) longistylis, TANAKA, 1957a, p. 83, pl. 5, figs. 13-16.

\section{Remarks :}

This species occurred more commonly in winter than in summer around Oahu Island.

In the subgenus Urocorycaeus the furcae in both sexes are very long, measuring at least twice the length of the rest of the abdomen, and almost parallel, diverging only slightly at the ends.

The female of $C$. (U.) longistylis is distinguished from the two allied species, $C$. (U.) lautus and $C$. (U.) furcifer, by its somewhat rounded genital segment which is often bent dorsally, and by its possession of a short rudimentary seta adjacent to a long seta on the endopodite of the 4th foot. The two bristles on the basal segments of the 2nd antenna are nearly the same length, as in the female of $C$. (U.) furcifer, but unlike the female of $C$. (U.) lautus. The specimens observed show fine hairs on the bristle on the 2 nd segment as in the male.

In the male the posterior margin of the abdomen of the 1st thoracic segment is serrated (DAKin and Colmfax, 1940), and the abdomen is not segmented into genital and anal segments, thus differing from the males of $C$. (U.) lautus and $C .(U$.$) furcifer. In the Hawaiian specimens of the male a rudi-$ mentary process was found next to the long seta on the endopodite of the 4th foot as described for the female. This is at variance with the description and figures given by M. DAHL (1912, p. 44, 47, 50, pl. 7, figs. 3, 4). (Although the 4th foot of the male is discussed on p. 50 and reference is made to figure 7 , this figure is indicated as the 4 th foot of the female in the legent.) Dakin and Colefax' figure (1940, fig. 188, d) of the 4th foot of the male $C$. (U.) longistylis also shows no trace of a spine. However, since the one-segmented abdomen was considered to be a significant characteristic of the male of $C$. $(U$.$) longistylis, the Hawaiian specimens were identified on this basis. It is$ noted that Mori's (1937, pl. 73, fig. 4) figure does in fact show a very short 
spine along with a long seta on the endopodite of the 4th foot in the male of this species.

This species was reported to breed in the East China Sea from January to March (CHIBA, 1956).

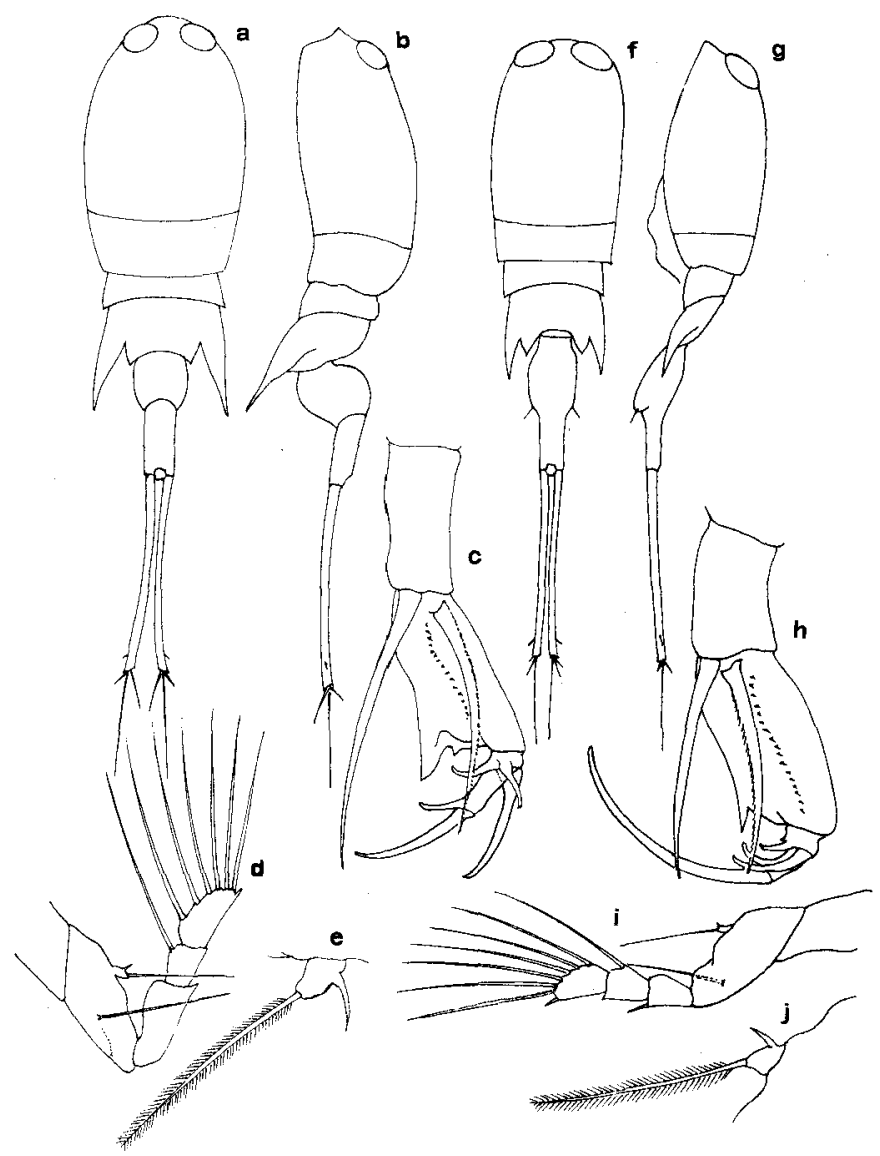

Fig. 11. Corycaeus (Urocorycaeus) longistylis

a. Female, dorsal, $\times 24, b$. Female, lateral, $\times 24, \quad c$. Female, 2nd antenna, $\times 85, d$. Female, 4th foot, $\times 85, e$. Female, endopodite of 4 th foot, $\times 350, f$. Male, dorsal, $\times 24, g$. Male, lateral, $\times 24$, $h$. Male, 2nd antenna, $\times 85, i$. Male, 4 th foot, $\times 85, j$. Male, endopodite of 4 th foot, $\times 350$

The male specimens in Hawaiian waters were comparatively large when compared with previously recorded specimens. The size of this species has been recorded as $2.54 \mathrm{~mm}$ (DANA, 1848, 1852-55); male, 2.0-2.1 mm (GIEsBrecht, 1892 , p. 671); female, 2.50-2.57 mm, male, 2.08-2.16 mm (M. DAHL, 1912); female, 
2.76-2.88 mm, male, 2.28-2.40 mm (FArran, 1929) ; female, $2.6 \mathrm{~mm}$, male, 2.16$2.24 \mathrm{~mm}$ (FARran, 1936); female, $2.65 \mathrm{~mm}$, male, $2.28 \mathrm{~mm}$ (Mori, 1937); male, $2.3 \mathrm{~mm}$ (Dakin and Colefax, 1940); female, $2.74 \mathrm{~mm}$ (Sewell, 1947); female, $2.80 \mathrm{~mm}$. male, 2.13-2.19 mm (TANAKA, $1957 \mathrm{a}$ ); and female, $2.74 \mathrm{~mm}$ (Olson, MS.).

Length: Female : $2.45-3.04 \mathrm{~mm}$ (average of 12 specimens, $2.71 \mathrm{~mm}$ ).

Male : $\quad 2.30-2.72 \mathrm{~mm}$ (average of 11 specimens, $2.51 \mathrm{~mm}$ ).

\section{Distribution :}

North Atlantic :

BRADY, 1883, as varius.

South Atlantic:

BRADY, 1883, as varius.

WOLFENDEN, 1911.

FARRAN, 1929.

Red Sea :

Thompson and A. Scott, 1903.

Arabian Sea :

Sewell, 1947.

Indo-Pacific :

BRADY, 1883, as various.

Giesbrecht, $1891,1892,1^{\circ} \mathrm{N}, 109^{\circ} \mathrm{W} ; 5^{\circ} \mathrm{N}, 115^{\circ} \mathrm{W}$.

Thompson and A. Scotт, 1903, from Suez to Geylon.

Bedot, 1909, Malay Archipelago.

SEWELL, 1947.

WILSON, 1950.

Tsuruta and Chiba, 1954, Mid-Pacific.

CHIBA et al. 1955, Bikini, Marshall Is.

Chiba and Tsuruta, 1955, west of Sunda Is.

ChibA et al. 1957, northern Indian Ocean.

Tsuruta et al. 1957, eastern Indian Ocean.

China Sea :

Dana, 1848, 1852-55.

MORI, 1937.

ChibA, 1956, East China Sea.

Japan Sea :

Tanaka, 1957 b, off Yamaguchi, Fukui and Kyoto.

South Pacific:

FARRAN, 1936, Great Barrier Reef.

Dakin and Colefax, 1940, off New South Wales, Australia. North Pacific:

AnRaku, 1952, off northern Japan.

Matsue and Komaki, 1953, Myojinsho off Japan. 
TANAKa, 1957 a, off Japan.

YAMAZI, 1958, Tanabe Bay, Wakayama.

Olson, (MS.), off west coast of North America.

Bering Sea :

WILson, 1950 ?

\section{Corycaeus (Urocorycaeus) lautus DANA, 1848}

(Fig. 12)

Corycaeus lautus DANA, 1948, p. 37.

Corycaeus lautus, DANA, 1852-55, p. 1219, pl. 85, figs, 12, a, a'-c.

Corycaeus lautus, F. DAHL, 1894, p. 69.

Corycaeus lautus, FARRAN, 1911, p. 288.

Corycaeus (Urocorycaeus) lautus, M. DAHL, 1912, p. 45, pl. 7, figs. 4-14.

Corycaeus (Urocorycaeus) lautus, Rose, 1929, p. 71, fig. 11.

Corycaeus (Urocorycaeus) lautus, Rose, 1933, p. 335, fig. 433.

Corycaeus lautus, MORx, 1937, p. 132, pl. 72, figs. 1-8.

Corycaeus (Urocorycaeus) lautus, DAKIN and CoLEFAX, 1940, p. 111, figs. 187, a, b.

Corycaeus (Urocorycaeus) lautus, TANAKA, 1957a, p. 84, pl. 6, figs. 1-2.

Remarks :

This species occurred in abundance both in winter and in summer, and appeared in the north to $33^{\circ} \mathrm{N}$.

The female is distinguished from the females of $C .\left(U_{.}\right)$longistylis and $C$. $(U$.$) furcifer by its rather slender genital segment which is about as long as$ the anal segment. The furcae are slightly longer than the rest of the abdomen, and therefore are shorter than those of the females of the other two species. A bristle on the 1st segment of the 2nd antenna is more than three times as long as the bristle on the 2 nd segment. In the females of $C$. (U.) longistylis and $C$. (U.) furcifer these two bristles are nearly equal in length. The endopodite of the 4 th foot bears two long setae, while one long seta and a rudimentary process are provided in $C$. (U.) longistylis and only one seta in $C$. $(U$. furcifer.

The male has a two-segmented abdomen. On the endopodite of the 4 th foot there is a distinct short spine beside a long seta. The proportional length of the furca to the rest of the abdomen in the male has been described as 1.2 (FARran, 1911, p. 288), 1.3 (M. DAhl, 1912, p. 47), 1.2 (Mori, 1937, pl. 72, fig. 8), 1.0 (Dakin and Colefax, 1940, fig. 187, a-d ?), and 1.3 (Tanaka, 1957a). The Hawaiian male specimens have slightly longer furca, having a ratio of 1.4 to the rest of the abdomen.

The body length of this species has been reported as female, $2.7-2.71 \mathrm{~mm}$, male, 2.09-2.36 mm (M. DAHL, 1912); female, $2.85 \mathrm{~mm}$, male, $2.3 \mathrm{~mm}$ from the North Temperate Atlantic, and female, $2.94 \mathrm{~mm}$, male, $2.3 \mathrm{~mm}$ from New Zealand waters (FARRAN, 1929); female, 2.75-2.94 mm, male, 2.15-2.5 mm (Rose, 1933); 
female, $2.7 \mathrm{~mm}$, male, $2.2 \mathrm{~mm}$ (Mori, 1937); female, $2.45 \mathrm{~mm}$, male, $1.45 \mathrm{~mm}$ (Dakin and Colefax, 1940); male, 2.29-2.32 mm (Tanaka, 1957 a); and male, $2.35 \mathrm{~mm}$ (Olson, MS.). The Hawaiian specimens were much longer than those

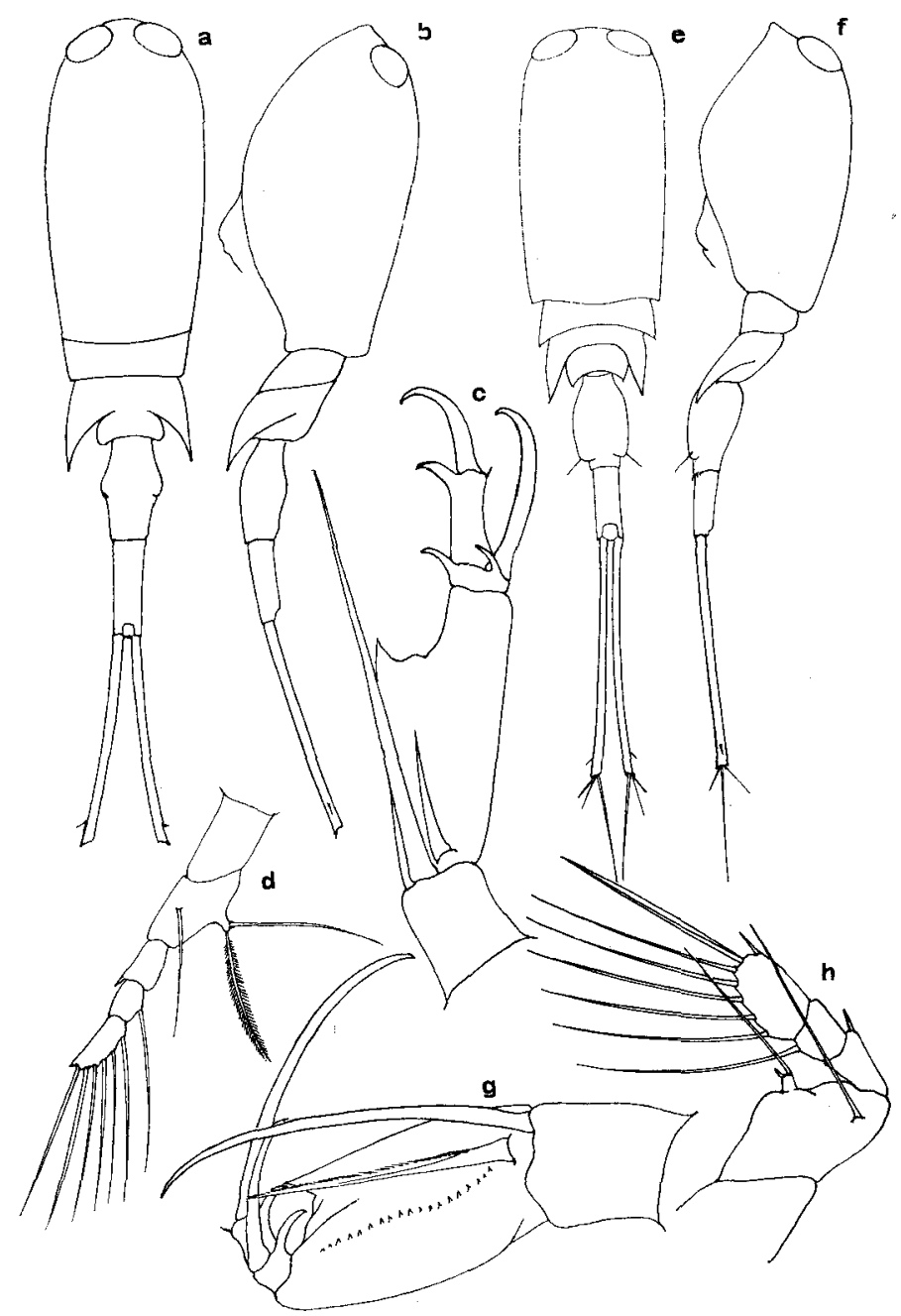

Fig. 12. Corycaeus (Urocorycaeus) lautus

a. Female, dorsal, $\times 31, b$. Female, lateral, $\times 31, c$. Female, 2nd antenna, $\times 130, d$. Female, 4th foot, $\times 85$, $e$. Male, dorsal, $\times 31$, $f$. Male, lateral, $\times 31, g$. Male, 2nd antenna, $\times 130, h$. Male, 4th foot, $\times 130$

previously reported. Only Farran's (1929) specimens from New Zealand waters are as large. 
Breeding was observed in the Bikini area, Tropical Pacific, from May to June (ChiBA, 1956).

Length: Female : 2.65-3.05 mm (average of 33 specimens, $2.94 \mathrm{~mm}$ ). Male : $2.20-2.55 \mathrm{~mm}$ (average of 28 specimens, $2.40 \mathrm{~mm}$ ).

Distribution:

Tropical, Subtropical and North Temperate Atlantic:

M. DAHL, 1912.

Candeias, 1926, off Portugal.

FARRAN, 1929.

Rose, 1929.

WILSON, 1942.

Klevenhusen, 1934, Subtropical and Tropical Atlantic.

Lysholm and NordgaArd, 1945, North Temperate Atlantic.

Moore, 1949, Bermuda.

Mediterranean :

Rose, 1934.

Caribbean Sea :

WILson, 1942.

Indo-Pacific :

DANA, 1848, 1852-55, Kingsmill.

Farran, 1911, Christmas I. in Indian Ocean.

M. DAHL, 1912.

MorI, 1942, Palau Is., western Caroline.

WILSON, 1942.

WILSON, 1950.

Tsuruta and Chiba, 1954, Mid-Pacific.

Chiba et al. 1955, Bikini, Marshall Is.

Chiba and Tsuruta, 1955, west of Sunda Is.

Chiba et al. 1957, northern Indian Ocean.

Tsuruta et al. 1957, eastern Indian Ocean.

East China Sea :

Morr, 1937.

Japan Sea :

Shimomura, 1954a, Noto Peninsula-Sado region.

Tanaka, $1957 \mathrm{~b}$, off Kyoto.

South Pacific:

FARRAN, 1936, Great Barrier Reef.

Dakin and Colefax, 1940, off New South Wales, Australia.

North Pacific:

Matsue and Komaki, 1953, Myojin Sho off Japan.

TANAKA, 1957a, off Japan. 
YAMAzI, 1958, Tanabe Bay, Wakayama.

Olson, (MS.), off west coast of North America.

\section{Corycaeus (Ditrichocorycaeus) asiaticus F. DAHL, 1894}

(Fig. 13)

Corycaeus asiaticus F. DAHL, 1894, p. 71.

Corycaeus (Ditrichocorycaeus) asiaticus, M. DAHL, 1912, p. 74, pl. 11, figs. 1-9.

Corycaeus (Ditrichocorycaeus) asiaticus, GuRNEY, 1927, p. 113, figs. 24, A-C. (female only).

Corycaeus asiaticus FARRAN, 1936, p. 137.

Corycaeus (Ditrichocorycaeus) asiaticus, DAkIN and ColefAx, 1940, p. 115, figs, 183, a, b.

Corycaeus (Ditrichocorycaeus) asiaticus, SEwELL, 1947, p. 281, fig. 70, D.

Corycaeus (Ditrichocorycaeus) asiaticus, TANAKA, 1957a, p. 87, pl. 6, figs. 13-19.

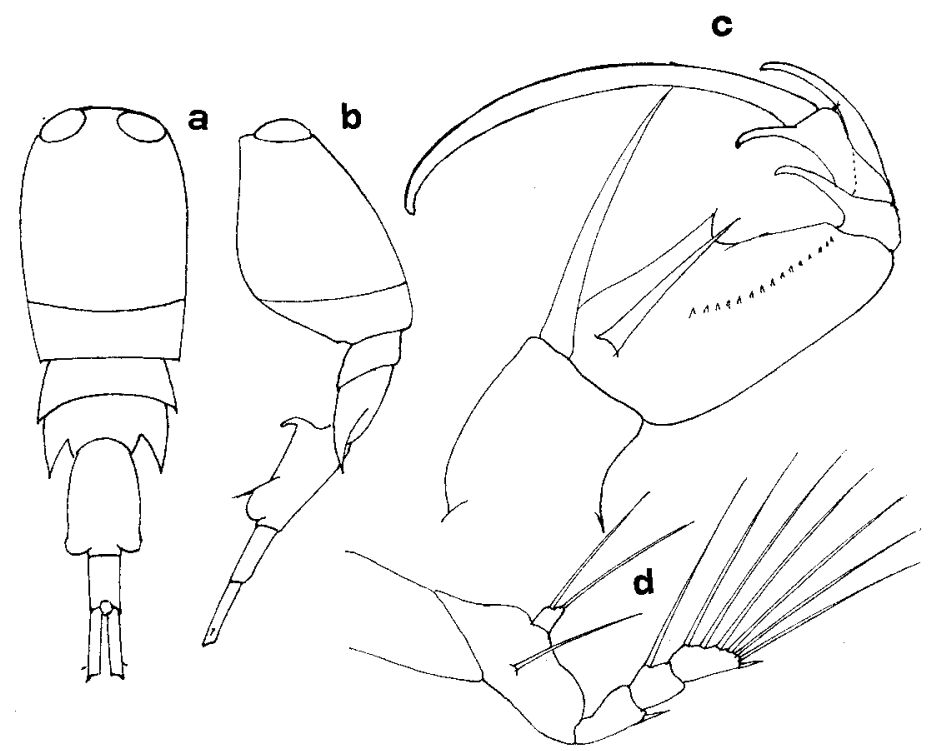

Fig. 13. Corycaeus (Ditrichocorycaeus) asiaticus

a. Male, dorsal, $\times 53$, b. Male, lateral, $\times 53$, c. Male, 2nd antenna,

$\times 220, d$. Male, 4 th foot, $\times 220$

\section{Remarks:}

A few males were found at a windward station off Oahu Island in winter.

This subgenus includes small-sized Corycaeus which have two setae on the endopodite of the 4 th foot.

FARRAN's (1911) C. murrayi (female) was synonymized with C. asiaticus by F. Dahl (1894), M. Dahl (1912), Wheeler (1901) and by Farran himself (1936). The male has a stout curved median hook at the ventral corner of the anterior end of the abdomen. Although the plankton samples examined in this study 
contained only one species of Ditrichocorycaeus, several other species of this subgenus, such as dubius, andrewsi, and subtilis, have been reported from coastal waters of the Pacific. Tanaka (1957a) reported a new species, C. (D.) dahli, from Japanese waters.

Length: Male : $1.1 \mathrm{~mm}$.

Distribution:

Suez Canal :

GuRney, 1927.

Arabian Sea :

SEwELL, 1947.

Indo-Pacific :

FARRAN, 1911, as murrayi, Chirstmas I. in Indian Ocean.

M. DAHL, 1912.

Mori, 1942, Palau Is., Western Caroline.

East China Sea :

MORI, 1937.

Japan Sea :

TANAKA, $1957 \mathrm{~b}$, off Yamaguchi and Kyoto.

South Pacific:

FARran, 1936, Great Barrier Reef.

Dakin and Colefax, 1940, off New South Wales, Australia.

North Pacific:

MORI, 1937, off Japan.

TANAKA, 1957a, off Japan.

YAMAZI, 1958, Tanabe Bay, Wakayama.

\section{Corycaeus (Onychocorycaeus) agilis DANA, 1848}

(Fig. 14)

Corycaeus agilis DANA, 1848, p. 37.

Corycaeus agilis, DANA, 1852-55, p. 1217, pl. 85, figs. 10, a, b.

Corycaeus gracilicaudatus, GIESBRBCHT, 1891, p. 481.

Corycaeus gracilicaudatus, GIESBRECHT, 1892, p. 674, pl. 51, figs. 15, 30.

Corycaeus agilis, F. DAHL, 1894, p. 72.

Corycaeus gracilicaudatus, A. SCOTT, 1909, p. 249.

Corycaeus gracilicaudatus, FARRAN, 1911, p. 290, pl. 11, figs. 11, 12.

Corycaeus (Onychocorycaeus) agilis, M. DAHL, 1912, p. 84, pl. 12, figs. 10-20.

Corycaeus (Onychocorycaeus) agilis, DAKIN and ColEFAx, 1940, p. 113, figs. 189, a-b.

Remarks :

Only females were found both in summer and in winter around Oahu Island.

This subgenus includes small-sized Corycaeus measuring less than $1.18 \mathrm{~mm}$

(M. DAHL, 1912). Giesbrecht's (1891, 1892) C. gracilicaudatus was synonymized 
with C. agilis Dana (male) (F. DAhL, 1894, M. DAHL, 1912), but not Cleve's (1910) C. gracilicaudatus (M. DAHL, 1912). A. Scotr's (1909) C. gracilicaudatus is considered synonymous with $C$. agilis, although he presented only a brief note on the characters of the female specimens. FARRAN (1911) noted that the distance between the terminal projections on the 3rd thoracic segment was less than the width of the posterior end of the 2nd thoracic segment. However, DANA's (1852-55) figures of C. agilis show widely separated terminal projections. The Hawaiian specimens which were identified as female C. (O.) agilis showed variations in the distance between the terminal projections of the 3rd thoracic segement. The genital segment of the female is enlarged at the middle, and
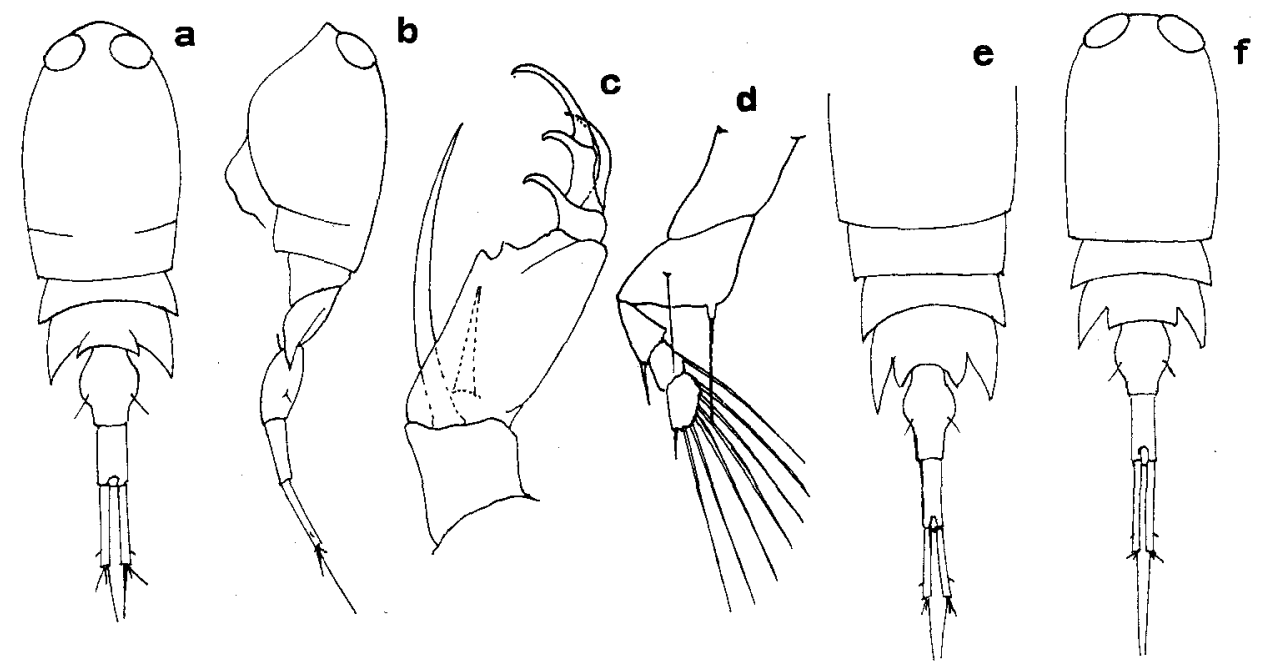

Fig. 14. Corycaeus (Onychocorycaeus) agilis

$a-d$. Specimen No. 1 , e. Specimen No. $2, f$. Specimen No. 3 ; a. Female, dorsal, $\times 53$, b. Female, lateral, $\times 53, \quad c$. Female, 2nd antenna, $\times 220$, d. Female, 4th foot, $\times 200$, e. Female, dorsal, omitting cephalus, $\times 53, f$. Female, dorsal, $\times 53$

is almost as long as the furca. The anal segment is slightly shorter than the furca, and more than twice as long as it is wide. The 2nd segment of the 2nd antenna is very broad, with two teeth on the distal inner margin. These teeth are not located at the same level of the distal end of the 2nd segment, but are slightly displaced from that level. A bristle on the 1st segment of the 2nd antenna is about 3 times as long as the shorter one on the 2nd segment. The endopodite of the 4 th foot bears a seta.

Length: Female : $1.00-1.16 \mathrm{~mm}$ (average of 8 specimens, $1.06 \mathrm{~mm}$ ).

Distribution:

Tropical and Subtropical Atlantic:

Giesbrecht, 1891,1892 , as gracilicaudatus, $3^{\circ} \mathrm{S}, 99^{\circ} \mathrm{W}$. 
KLevenhusen, 1934, Tropical and Subtropical Atlantic.

WILSON, 1942.

Caribbean Sea :

WILSON, 1942.

Indo-Pacific :

Dana, 1848, 1852-55, Tongatabu, Tropical Pacific.

GiesbreCht, 1891,1892 , as gracilicaudatus, $0^{\circ}, 180^{\circ} ; 5^{\circ} \mathrm{N}, 11^{\circ} \mathrm{W}$.

A. ScotT, 1909, as gracilicaudatus.

M. DAHL, 1912.

WILSON, 1942.

Japan Sea :

TANAKA, $1957 \mathrm{~b}$, off Kyoto.

South Pacific:

Dakin and Colefax, 1940, off New South Wales, Australia. North Pacific:

ANRAKU, 1952, off northern Japan.

MaEdA, 1956, Tsugaru Straits, northern Japan.

12. Corycaeus (Onychocorycaeus) latus DANA, 1848

(Fig. 15)

Corycaeus latus DANA, 1848 , p. 38.

Corycaeus laticeps, DANA, 1848, p. 37.

Corycaeus latus, DANA, 1852-55, p. 1221, pl. 86, figs. 3, a, a'-e.

Corycaeus laticeps, DANA, 1852-55, p. 1215 , pl. 85 , figs. 8 , a-c.

Corycaeus latus, F. DAHL, 1894, p. 72.

Corycaeus (Onychocorycaeus) latus, M. DAHL, 1912, p. 93, pl. 13, figs. 1-8.

Corycaeus (Onychocorycaeus) latus, Rose, 1933, p. 331, fig. 428.

Corycaeus (Onychocorycaeus) latus, DAKIN and ColeFAx, 1940, p. 113, figs. 191, a, b.

\section{Remarks :}

A few specimens were collected in winter and summer around Oahu Island.

DANA's (1848, 1852-55) C. laticeps was synonymized with this species (M. DAHL, 1912).

The male has no ventral hook on the antero-ventral corner of the genital segment. The genital segment is slightly shorter than the combined length of the anal segment and the furca. The anal segment is about 2.3 times as long as breadth. The length of the terminal claw of the 2 nd antenna exceeds the combined length of the 1st and 2nd segments of this antenna.

Breeding was observed in the Bikini area, Tropical Pacific, in May and June (ChibA, 1956).

Length: Male: $1.0 \mathrm{~mm}$. 
Distribution :

Tropical and Subtropical Atlantic:

Dana, $1848,1852-55,3^{\circ} 45^{\prime} \mathrm{N}$ to $4^{\circ} 20^{\prime} \mathrm{N}, 19^{\circ} 30^{\prime} \mathrm{W}$ to $18^{\circ} 30^{\prime} \mathrm{W} ; 6^{\circ} 20^{\prime} \mathrm{S}, 24^{\circ} \mathrm{W}$.

DANA, $1848,1852-55$, as laticeps, $4^{\circ} \mathrm{N}$ to $5^{\circ} \mathrm{N}, 19^{\circ} \mathrm{W}$ to $22^{\circ} \mathrm{W} ; 0^{\circ} 15^{\prime} \mathrm{S}$ to $1^{\circ} \mathrm{S}, 18^{\circ} 30^{\prime} \mathrm{W}$ to $31^{\circ} \mathrm{W}$.

M. DAHL, 1912.

FARRAN, 1929.

Rose, 1929.

Klevenhusen, 1934, Tropical Atlantic.
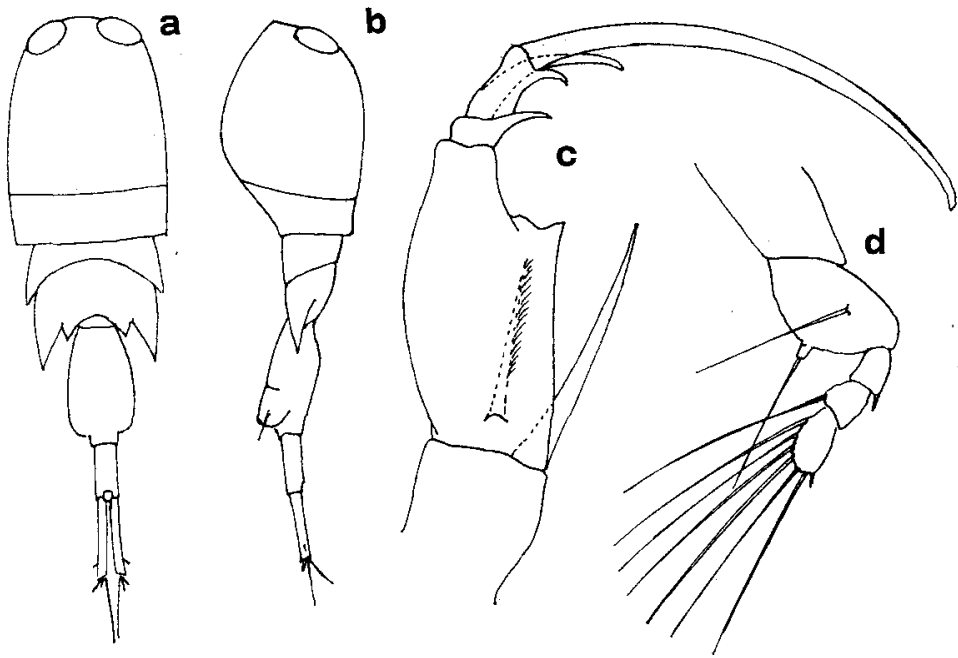

Fig. 15. Corycaeus (Onychocorycaeus) latus

$a$. Male, dorsal, $\times 53, b$. Male, lateral, $\times 53, c$. Male, 2nd antenna, $\times 220, d$. Male, 4 th foot, $\times 220$

\section{Mediterranean :}

M. DAHL, 1912.

Rose, 1929.

Japan Sea :

Shimomura, 1953, Nanao Bay.

South Pacific:

Dakin and Colefax, 1940, off New South Wales, Australia.

North Pacific:

AnRaku, 1952, off northern Japan. 
13. Corycaeus (Onychocorycaeus) catus F. DAHL, 1894

(Fig. 16)

Corycaeus catus F. DAHL, 1894, p. 72.

?Corycaeus obtusus, DANA, 1848, p. 36 .

?Corycaeus arientalis, DANA, 1848, p. 37.

?Corycaeus obtusus, DANA, 1852-55, p. 1214, pl. 85, fig. 6 .

?Corycaeus orientalis, DANA, $1852-55$, p. 1218, pl. 85 , figs. 11 , a-c.

Corycaeus obtusus (part), GIESBRECHT, 1891, p. 481.

Corycaeus obtusus (part), GIESBRECHT, 1892, p. 673, pl. 51, figs. 12-14.

Corycaeus catus, FARRAN, 1911, p. 290, pl. 12, figs. 1-3.

Corycaeus (Onychocorycaeus) catus, M. DAHL, 1912, p. 99, pl, 13, figs. 17-24.

Corycaeus latus, MoRI, 1937, p. 136, pl. 74, figs. 8-10, (not C. catus, p. 135, pl. 74, figs. 1-7,) (ref. TANAKA, 1957a).

Corycaeus (Onychocorycaeus) catus, TANAKA, 1957a, p. 94, pl. 9, figs. 6-12.

\section{Remarks :}

A few female specimens were found at four stations in winter, and at one station in summer around Oahu Island, and at one station on $30^{\circ} \mathrm{N}$. in summer.

M. DAHL (1912) synonymized DaNA's $(1848,1852-55)$ C. obtusus and C. orientalis, and Giesbrecht's (1891, 1892) C. obtusus (as part) with this species.

The body is extremely robust. The anterior body is about twice as long as the abdomen including the furca. The genital segment is longer than the combined length of the abdomen and the furca. The anal segment is about 1.3 times as long as it is broad, and slighly shorter than the furca. Mori's (1937) $C$. latus was synonymized by TANAKA (1957a) with $C$. catus. The female of $C$. (O.) catus from Hawaiian waters is generally larger than those previously recorded. They have been reported with the following lengths : $1.97 \mathrm{~mm}$ (DANA, $1848,1852-55$, as obtusus) ; $1.27 \mathrm{~mm}$ (DANA, 1848, 1852-55, as orientalis) $0.95 \mathrm{~mm}$ (M. DAhl, 1912); $1.0 \mathrm{~mm}$ (Mori, 1937, as latus); $1.0 \mathrm{~mm}$ (DAKIN and Colefax, 1940); and 0.93-1.0 mm (TANAKA, 1957 a).

Breeding was observed in the Sunda Chain area in December and January (CHIBA, 1956).

Length: Female : $1.09-1.18 \mathrm{~mm}$ (average of 9 specimens, $1.14 \mathrm{~mm}$ ).

Distribution:

Arabian Sea :

SEWELL, 1947.

Indo-Pacific :

DanA, 1848, 1852-55, as obtusus, El Gran Cocal.

Dana, 1848, 1852-55, as orientalis, Sulu Sea.

FARran, 1911, Christmas I. in Indian Ocean.

M. DAHL, 1912.

WILSON, 1942. 
WiLson, 1950.

Tsuruta and Chiba, 1954, Mid-Pacific.

Chiba et al. 1955, Bikini, Marshall Is.

Chiba and Tsuruta, 1955, west of Sunda Islands.

Chiba et al. 1957, northern Indian Ocean.

Tsuruta et al. 1957, eastern Indian Ocean.

\section{East China Sea :}

Mori, 1937, as latus.

\section{Japan Sea :}

Kokubo and Sato, 1947, Jusan Gata, Aomori.

TANAKA, $1957 \mathrm{~b}$, off Kyoto.
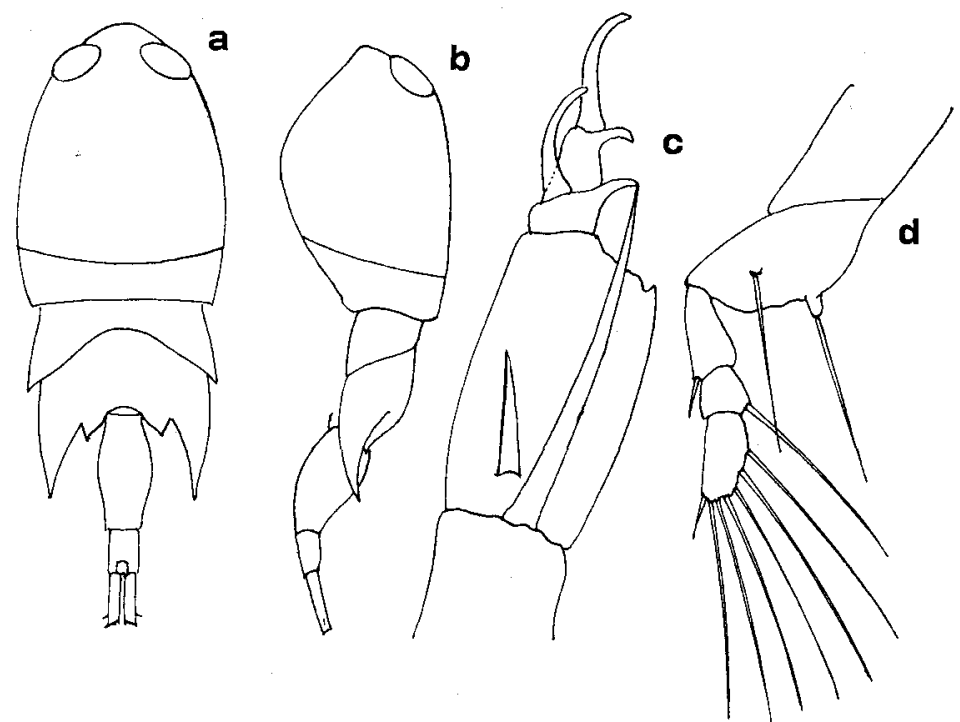

Fig. 16. Corycaeus (Onychocorycaeus) catus

$a$. Female, dorsal, $\times 53, b$. Female, lateral, $\times 53, c$. Female, 2nd antenna, $\times 220, d$. Female, 4 th foot, $\times 220$

South Pacific:

FARran, 1936, Great Barrier Reef.

Dakin and Colefax, 1940, off New South Wales, Australia.

North Pacific:

Mori, 1937, as latus, off Japan.

Tokioka and Yamazi, 1950, Ago Bay, Mie.

MaedA, 1956, Tsugaru Straits.

TANAKA, 1957a, off Japan.

Bering Sea :

WILSON, 1950 ? 


\section{Corycaeus (Onychocorycaeus) sp. young female}

(Fig. 17)

One specimen was obtained. A bristle on the 2nd basal segment on the 2nd antenna is provided with spinules as in Farranula. However, the bristle on the 1st basal segment is naked. The head is separated from the 1st thoracic segment, and the 2nd and 3rd thoracic segments are distinctly separated. The genital segment is separated from the anal segment and bears paired spines on its dorsal surface. It is probable that the paired spines (homologous to the 6th feet) on the genital segment are located ventrally in younger stages, but, in

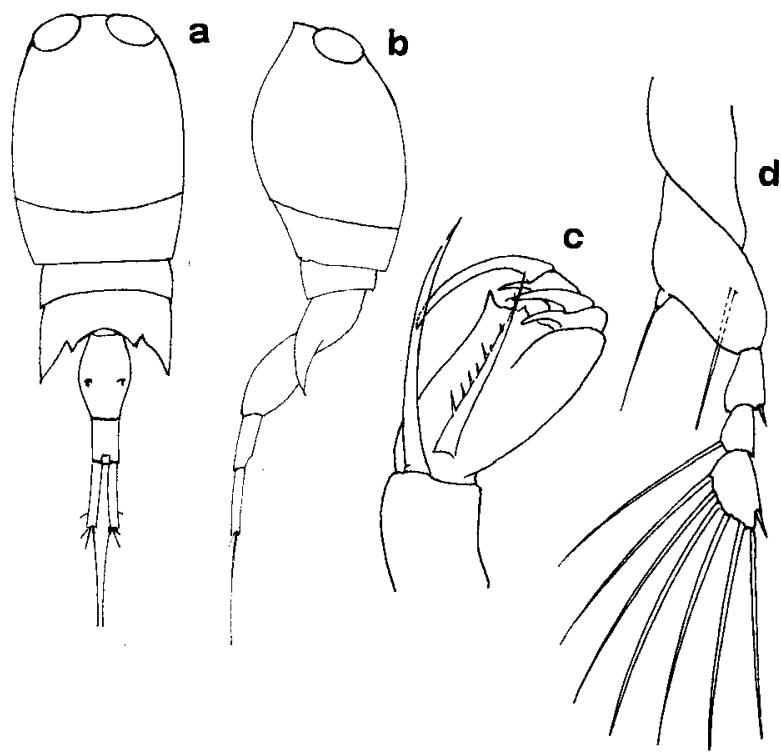

Fig. 17. Corycaeus (Onychocorycaeus), young female

a. Dorsal, $\times 53$, b. Lateral, $\times 53$, c. 2 nd antenna, $\times 220$,

d. 4 th foot, $\times 220$

the female, they become located dorsally in later stages. By having the dorsal spines on the genital segment and the presence of spinules on the bristle on the 2nd basal segment of the 2nd antenna, this specimen is considered to be young form. General appearance suggests that this specimen is young female of subgenus Onychocorycaeus. The length, including furcae, is $0.95 \mathrm{~mm}$.

\section{Young forms of Corycaeus}

(Figs. 18-26)

A considerable number of specimens with characters resembling Rose's 
(1928) Mimocorycella having (1) spinules on two bristles of the basal segments of the 2nd anntena and (2) an endopodite on the 4th foot (except for specimen, No. 8), were obtained at several stations. Rose (1929, p. 73) established the genus Mimocorycella as distinguished from Corycaeus and Farranula (=Corycella). He described "Abdomen á un article dans les deux sexes. Absence complète de toute carène ventrale prolongée en bac chez la femelle. Quatrième segment thoracique séparé du troisième, doux deux prolongés en pointed latérales. Soies $\mathrm{du}$ basipodite de la seconde antenne, remeuses comme dans le genre Corycella.

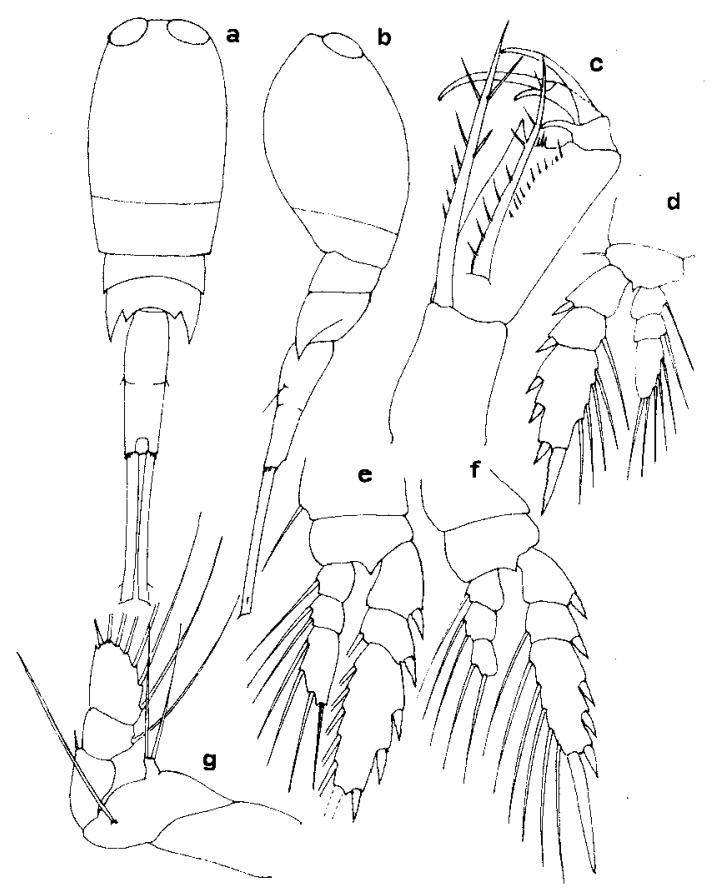

Fig. 18. Corycaeus, young (=Mimocorycella), Specimen No. 1

a. Dorsal, $\times 31, b$. Lateral, $\times 31, c .2$ nd antenna, $\times 130$,

d. 1st foot, $\times 85, e$. 2nd foot, $\times 85, \quad$ f. 3rd foot, $\times 85$,

g. 4th foot, $\times 130$

Deuxième article basal de l'antenne postérieure avec une forte dent interne. Exopodite des trois premières paires de pattes thoraciques avec 1, 1, 3 soies externes. Quatrième patte avec un endopodite en forme de bouton portant une soie plumeuse; exopodite avec $1,0,1$ soies externes, parfois remplacées par des aiguillons." However, he was somewhat skeptical as shown on page 74, "Mais l'étude de la litterature concernant les Corycaeidae m'a démontré que chez les formes jeunes de Corycaeus, on trouvait précisément ces caractères spéciaux...... Comme dans le cours de cette évolution, qui semble se faire par 
mues sans doute assez nombreuses, un stade paraît assez général et assez important, je crois qu'ily a intérêt à le définier par un mot. C'est le stade où les caractères sont intermédiaires entre ceux des genres Corycella et Corycaeus. Je propose le nom de Mimocorycella qui me paraît expressif, et je décris ici deux formes particulières. Plus tard, lorsque nos connaissances auront fait des progrès suffisants, il sere sans doute possible de rattacher les Mimocorycella bien décrites à des espèces adultes connues. Et ainsi l'évolution des Corycaeidae, s'éclaircira pour ainsi dire automatiquement." Although still somewhat

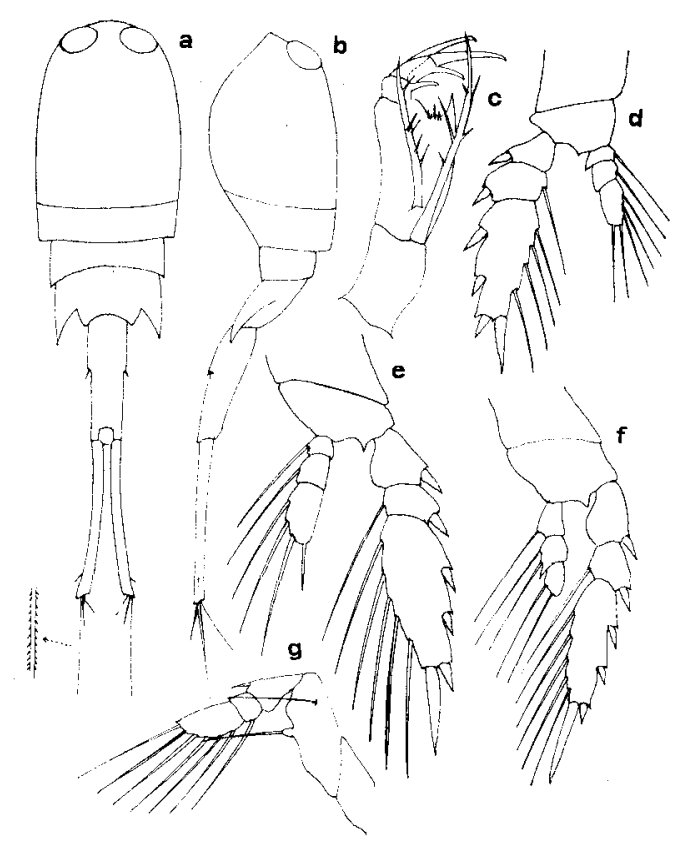

Fig. 19. Corycaeus, young (=Mimocorycella), Specimen No. 2

a. Dorsal, $\times 31, b$. Lateral, $\times 31, \quad c .2$ nd antenna, $\times 85$, d. Ist foot, $\times 85, e$. 2nd foot, $\times 85, f$. 3rd foot, $\times 85$, g. 4th foot, $\times 85$

uncertain, he still persisted in separating Mimocorycella (Rose, 1933, p. 336) from Corycaeus and Farranula (=Corycella). "Ces caractères ont une valeur générique incontestable, et permettent de séparer ce genre de précédent (Corycella). Mais il faut savoir que les stades jeunes de Corycaeus, au moins dans certaines espèces, passent par une forme avec soies rameuses à $A_{2}$ (2nd antenna), abd. à 1 art. C'est le stade Mimocorycella Rose, qui sera toujours facile à distinguer par l'absence de bec chez la 우, et les Se (external spines) de Re (exopodite) qui sont celles de Corycaeus." 
F. DAHL (1894, p. 72, fig. 2) mentioned the characters of young stages of Corycaeus that "Ueber einstimmend sind besonders die fast gleich Länge der Borsten der Hinterantennen, die Befiederung und fast gleiche Länge der Borsten an den Grundgliedern dieser Antennen und das eingliedrige Abdomen. Beim ausgebildeten Thier schwindet die Fiederung der Borsten." These characters of young forms have also been discussed by KLAVENHUSEN (1933) and Krishnaswamy (1953, p. 71, fig. 14). KLEVEnhusen (1933) examined specimens of a young male Corycella gracilis of $0.62 \mathrm{~mm}$ (adult male, $0.8 \mathrm{~mm}$.), a young female of $0.9 \mathrm{~mm}$ (adult female, $1.0 \mathrm{~mm}$ ), and a young male Onychocorycaeus giesbrechti of $0.79 \mathrm{~mm}$ (adult male, $0.78-0.9 \mathrm{~mm}$ ), and stated that the anterior

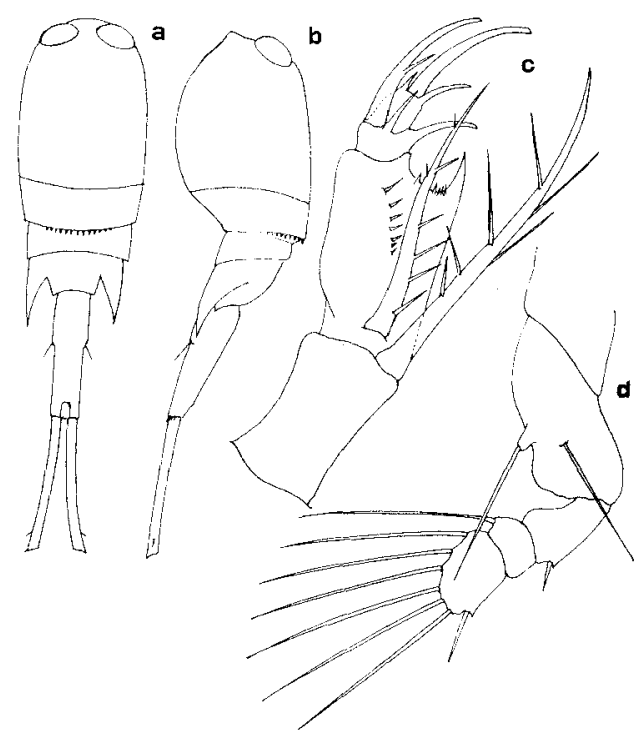

Fig. 20. Corycaeus young ( $=$ Mimocorycella), Specimen No. 3

a. Dorsal, $\times 31, b$. Lateral, $\times 31, c .2$ nd antenna, $\times 130$,

d. 4 th foot, $\times 130$

part of the body of these young forms does not differ from that of adults, but the abdomen always shows certain undeveloped features : the abdomen of young forms in more slender than in the adults, and in young Onychocorycaeus giesbrechti the anal segment is not yet separated from the genital segment. Two bristles on the basal segments of the 2nd antenna have spinules as in adult Corycella, but in these young males the terminal claw of the 2nd antenna is not yet elongated, thus differing from that of the adult males. The young male and female Corycella gracilis, like the adults, have no endopodite on the 4th foot. The young male Onychocorycaeus giesbrechti has an endopodite which 
bears a long seta (KLevenhusen, 1933, figs. 7, 9).

Nine specimens were selected from the specimens which are identical with Mimocorycella and arranged by size as follows :

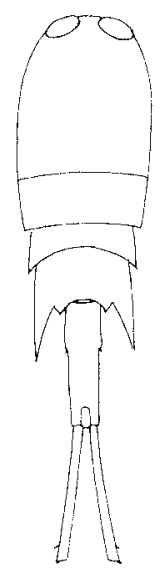

Fig. 21. Corycaeus, young (=Mimocorycella), Specimen No. 4, dorsal, $\times 35$

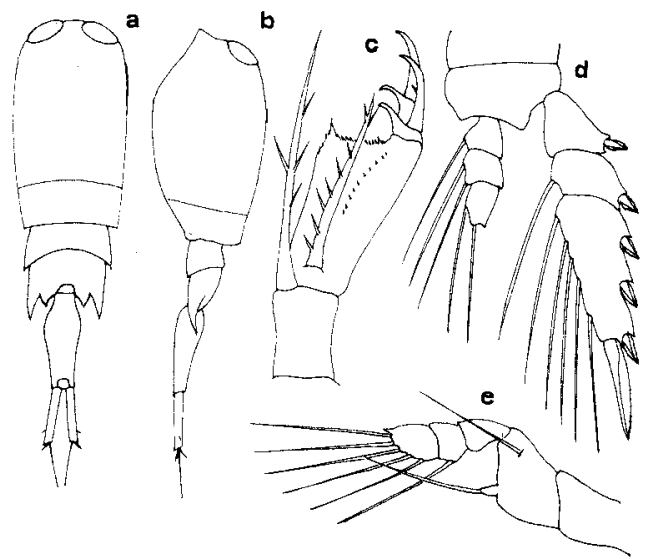

Fig. 22. Corycaeus, young ( $=$ Mimocorycella), Specimen No. 5

$a$. Dorsal, $\times 35, b$. Lateral, $\times 35, \quad c .2$ nd antenna, $\times 130$,

d. 2nd foot, $\times 130$, e. 4 th foot, $\times 130$

No. $1 \quad 1.94 \mathrm{~mm}$.

No. $2 \quad 1.93 \mathrm{~mm}$.

No. $3 \quad 1.73 \mathrm{~mm}$.

No. $4 \quad 1.60 \mathrm{~mm}$. 


$\begin{array}{ll}\text { No. } 5 & 1.20 \mathrm{~mm} . \\ \text { No. } 6 & 1.15 \mathrm{~mm} . \\ \text { No. } 7 & 0.81 \mathrm{~mm} . \\ \text { No. } 8 & 0.77 \mathrm{~mm} . \\ \text { No. } 9 & 0.73 \mathrm{~mm} .\end{array}$

Specimen No. 1 differs from the others by having two setae on the endopodite of the 4th foot (Rose, 1929, p. 80, showed that the male Mimocorycella pestai,

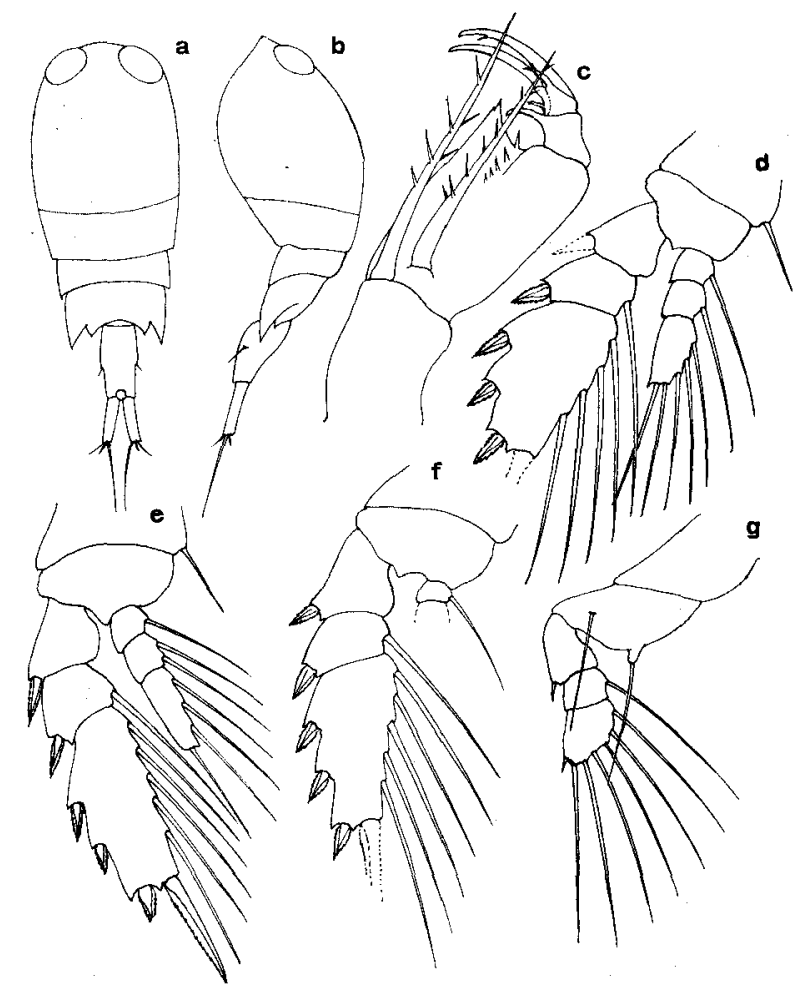

Fig. 23. Corycaeus, young (=Mimocorycella), Specimen No. 6 a. Dorsal, $\times 35, b$. Lateral, $\times 35, c$. 2nd antenna, $\times 150$, $d$. 1st foot, $\times 130, e$. 2nd foot, $\times 130, f$. 3rd foot, $\times 130$, g. 4 th foot, $\times 150$

$2.5 \mathrm{~mm}$. in length, has two setae on the endopodite of the 4th foot). In the specimens examined the arrangement of the external spines on the exopodites of the 1st to 3rd feet agrees with the description of the genus Mimocorycella (specimens Nos. 1, 3,6 and 7), but not with Corycaeus. In the small specimens (Nos. 8 and 9), there is a peculiar cephalothorax which protrudes into rounded projections at the two sides. This protrusion is not apparent in specimens 
larger than $0.81 \mathrm{~mm}$. In the smallest specimen (No. 9), there is a semicircular ventral process like that of adult Corycaeus and of adult male of Farranula. In all specimens of various sizes the terminal claw of the 2nd antenna is not elongated, about the same length as on the 1st segment (which is shorter in adult). The genital spines (homologous to the 6 th feet) are always ventral. In general, these paired spines on the genital segment are dorsal in the adult female and ventral in the adult male. The author believes that these spines change their position during successive moult. Therefore, the sex in the young stages cannot be determined by the position of these spines. On a $0.77 \mathrm{~mm}$.

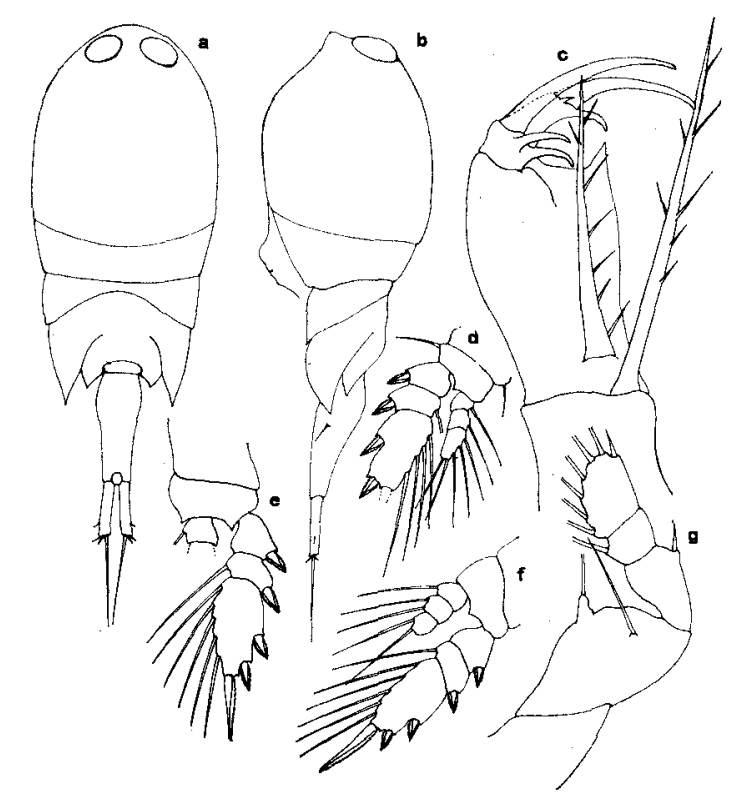

Fig. 24. Coryeaus, young (=Mimocorycella), Specimen No. 7

a. Dorsal, $\times 64, b$. Lateral, $\times 64, \quad c .2$ nd antenna, $\times 270$, d. 1st foot, $\times 100, e$. 2nd foot, $\times 100, f$. 3rd foot, $\times 100$, g. 4 th foot, $\times 270$

specimen (No. 8), and a $0.73 \mathrm{~mm}$. specimen (No. 9), both exopodite and endopodite of the 1st and 2nd feet are two-segmented. Although in one specimen (No. 9) the 3 rd foot has a two-segmented exopodite (the endopodite was lost), in the other specimen (No. 8), the 3rd foot has a one-segmented exopodite and endopodite. The furcae of one specimen (No. 9) are not yet separated from the anal segment, and they are provided with wide toothed spines at inner distal ends. The body and appendages of this specimen were filled with a granular material, perhaps indicating that this copepod was about moult. It should be 
noted that, in the other specimen (No. 8), the endopodite on the 4th foot is entirely absent. This is not characteristic of Mimocorycella, but rather characteristic of Farranula. However, it is probable that the endopodite will develop in later stages as happened in the larger specimens (Nos. 1-7). The

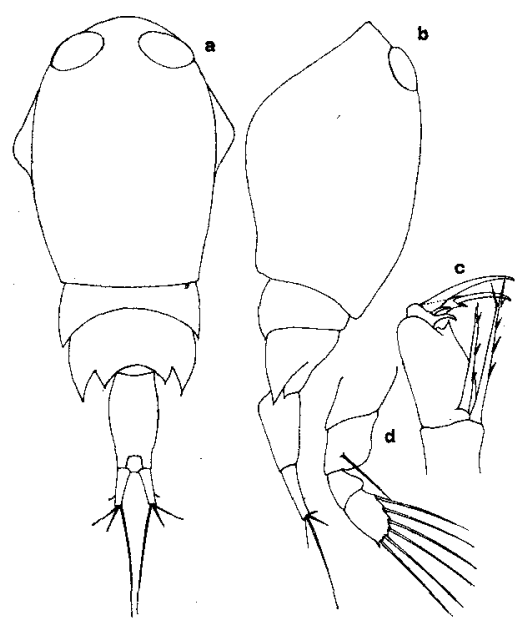

Fig. 25. Corycaeus, young (=Mimocorycella), Specimen No. 8

a. Dorsal, $\times 64, b$. Lateral, $\times 64, \quad c$. 2nd antenna, $\times 110$, d. 4 th foot, $\times 110$

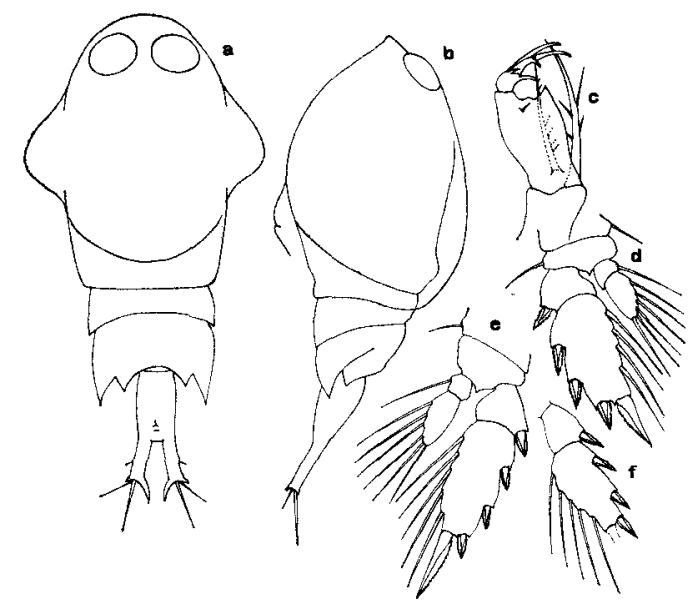

Fig. 26. Corycaeus, young (=Mimocorycella), Specimen No. 9

$a$. Dorsal, $\times 64, b$. Lateral, $\times 64, c$. 2nd antenna, $\times 110$, $d$. 1st foot, $\times 100, e$. 2nd foot, $\times 100, f$. exopodite of 3rd foot, $\times 100$ 
4th feet of the smallest specimen (No. 9) were lost and not examined. In one specimen (No. 5), there are only five setae on the 3rd segment of exopodite of the 4th foot, and in another (No. 8), the seta on the 2nd segment of exopodite of the 4th foot is absent.

Rose (1929) described Mimocorycella pestai (female, $1.75 \mathrm{~mm}$, male, $2 \mathrm{~mm}$, $2.5 \mathrm{~mm}$ ) and Mimocorycella anna (female, $1.25 \mathrm{~mm}$ ) as new species. The female specimen $(2 \mathrm{~mm})$ reported by Pesta (1914, Bull. I'Inst. Oceanogr. Monaco, No. 280) and named Mimocorycella pestai by Rose (1929) resembles the Hawaiian specimens, but the latter are larger than $1.6 \mathrm{~mm}$.

The author considers that Mimocorycella is a doubtful genus. The slender undeveloped abdomen leads us to believe that they are the young stages of another genus, probably Corycaeus. The short terminal claw on the 2nd antenna (in male) is also characteristic of young stages, although it should be remembered that in the adult male of the subgenus Monocorycaeus the terminal claw is not elongate. Similarly, (in female) the ventral position of the genital spines is characteristic of young stages.

\section{Genus Farranula WILson, 1932}

Corycella FARRAN, 1911, p. 283.

Farranula WILSON, 1932, p. 594, foot note.

Farranula, WiLson, 1950, p. 227.

This genus was separated from genus Corycaeus by FARRAN (1911) under the generic classification of Corycella, because the female possesses the characteristic beak-shaped ventral process. The female of Corycaeus has a semicircular ventral process. He placed Corycella gibbulus as the type of genus. Later, WILson $(1932,1950)$ pointed out that the name Corycella had been used by LÉGER in 1893 for a genus of Protozoa, and proposed that the name Farranula be substituted for Corycella.

\section{Farranula gibbula (GIESBRECHT), 1891}

(Fig. 27)

Corycaeus gibbulus GIESBRECHT, 1891, p. 481.

Corycaeus gibbulus, GIESBRECHT, 1892, p. 675, pl. 51, figs. 22, 23.

Corycaeus gibbulus, F. DAHL, 1894, p. 69.

Corycella gibbula, FARRAN, 1911, p. 284.

Corycella brevis, FARRAN, 1911, p. 285, pl. 10, figs. 1-6, pl. 11, fig. 7.

Corycaeus (Corycella) gibbulus, M. DAHL, 1912, p. 115, pl. 15, figs. 1-4, 9, 10, 25, 35, 36.

Corycaeus gibbulus, MORI, 1937, p. 137, pl. 76, figs. 12-16, pl. 77, figs. 1-4.

Corycaeus (Corycella) gibbula, KRISHNASWAMY, 1953, p. 72, figs. 15, 16.

Corycaeus (Corycella) gibbulus, TANAKA, 1957a, p. 96, pl. 10, figs. 6 11 . 
Remarks :

This species occurred rather commonly both in winter and in summer around Oahu Island.

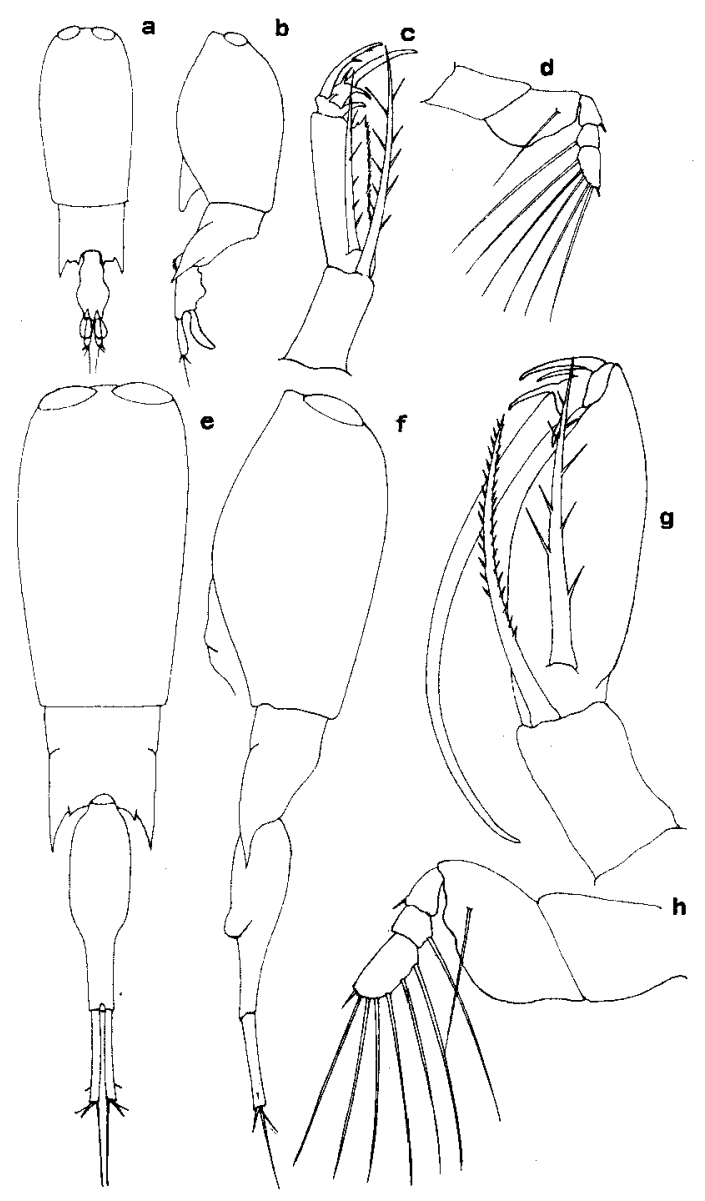

Fig. 27. Farranula gibbula

$a$. Female, dorsal, $\times 35, b$. Female, lateral, $\times 35$, $c$. Female, 2nd antenna, $\times 150, d$. Female, 4th foot, $\times 150$, e. Male (Specimen No. 1), dorsal, $\times 85$, $f$. Male (Specimen No. 1), lateral, $\times 85, g$. Male (Specimen No. 2), 2nd antenna, $\times 350, h$. Male (Specimen No. 2), 4th foot, $\times 350$

FARRAN (1911) reported a new species, Corycella brevis, together with this species from Christmas Island. He found one female specimen of C. brevis, and distinguished it from C. gibbulus mainly by the form of its abdomen. However, M. DAHL (1912) was of the opinion that FARRAn's (1911) C. brevis was 
probably an immature form of $C$. gibbulus. The abdomen of the female of $C$. brevis described by FARRAN (1911, pl. 10, figs. 1, 2;0.85 $\mathrm{mm}$ in length) is smoother in contour than that of M. DAHL's (1912) C. gibbulus (1.0-1.05 $\mathrm{mm}$ in length), and the abdomen in GiesBrecht's (1892, p. $671 ; 0.9-0.95 \mathrm{~mm}$ in length) female specimens appear intermediate in shape between M. DAHL's gibbulus and FARRAN's brevis. The Hawaiian specimens agree most closely with M. DAHL's descriptions and figures.

The anterior body of the female is about 2.4 times as long as the abdomen. The 4th thoracic segment projects into a small blunt process on each side at the inner distal corner, but it is not sure whether it corresponds to the process described by KRISHNASWAMY (1953). The abdominal segment is about 1.7 times as long as the furca. In FARran's (1911) specimens the furca is contained 2-1/4 times in the rest of the abdomen. In the female specimen shown in Fig. 27, the 3rd segment of exopodite of the 4 th foot bears only five setae instead of six setae.

The male of this species is difficult to distinguish from the male of Farranula concinna. They are usually separated by their sizes. The larger forms $(0.85 \mathrm{~mm})$ are assumed to be male gibbula and the smaller forms $(0.78-0.8 \mathrm{~mm})$ as male concinna (M. DAHL, 1912, p. 116). TANAKA (1957a, p. 96) also divided the males into two species on the basis of size; gibbula with the larger body $(0.80-0.87 \mathrm{~mm})$ and concinna with the smaller $(0.73-0.78 \mathrm{~mm})$. KRISHNASWAMY (1953) obtained male specimens of gibbula which were $0.9 \mathrm{~mm}$ long.

Length: Female : $0.9-1.03 \mathrm{~mm}$ (average of 17 specimens, $0.97 \mathrm{~mm}$ ).

Male : $\quad 0.85-0.88 \mathrm{~mm}$ (average of 3 specimens, $0.86 \mathrm{~mm}$ ).

\section{Distribution:}

Atlantic :

WiLson, 1942,

Red Sea :

Thompson and A. Scott, 1903.

Arabian Sea :

SEWELL, 1947.

Indo-Pacific :

Giesbrecht, $1891,1892,3^{\circ} \mathrm{S}, 99^{\circ} \mathrm{W} ; 0^{\circ}, 108^{\circ} \mathrm{W} ; 5^{\circ} \mathrm{N}, 115^{\circ} \mathrm{W} ; 15^{\circ} \mathrm{N}, 138^{\circ} \mathrm{W}$.

Thompson and A. Scott, 1903, Suez to Ceylon.

Bedot, 1909, Malay Archipelago.

A. Scott, 1909.

FARRAN, 1911, Christmas I. in Indian Ocean.

FarRan, 1911, as brevis, Christmas I. in Indian Ocean.

M. DAHL, 1912.

MoRI, 1942, Palau Is., western Caroline.

WILSON, 1942. 
WILSON, 1950.

KrishnasWAmy, 1953, off Madras coast.

Tsuruta and Chiba, 1954, Mid-Pacific.

Chiba et al. 1955, Bikini, Marshall Is.

Chiba and Tsuruta, 1955, west of Sunda Is.

Снiba et al. 1957, northern Indian Ocean.

Tsuruta et al. 1957, eastern Indian Ocean.

East China Sea :

Mori, 1937.

Japan Sea :

TANAKA, 1957b, off Kyoto.

South Pacific :

Farran, 1936, Great Barrier Reef.

Dakin and Colefax, 1940, off New South Wales, Australia.

North Pacific:

MoRI, 1937, off Japan.

Maekawa et al. 1953, Suhô-Nada, Inland Sea of Japan.

TANAKA, 1957a, off Japan.

Yamazi, 1958, Tanabe Bay, Wakayama.

\section{Farranula carinata (GIESBRECHT), 1891}

(Fig. 28)

Corycaeus carinatus Giesbrecht 1891, p. 481.

Corycaeus pellucidus, BRADY, 1883, p. 112, pl. 52, fig. 19.

Corycaeus carinatus, GIESBRECHT, 1892, p. 675, pl. 51, figs. 20, 26.

Corycaeus carinatus, F. DAHL, 1894, p. 69.

Corycaeus carinatus, WHEELER, 1899, p. 192, fig. 30.

Corycaeus carinatus, Esterly, 1905, p. 226, figs. 62, a, b.

Corycaeus carinatus, A. Scotr, 1909, p. 246.

Corycella carinata, FARRAN, 1911, p. 286, pl. 11, fig. 10.

Corycaeus (Corycella) carinatus, M. DAHL, 1912, p. 118, pl. 15, figs. 7, 8, 13, 14, 21, 22, 31, 32.

Corycella carinata, WILSON, 1932a, p. 362, figs. 220 , a, b.

Corycella carinata, Rose, 1933, p. 336, fig. 435.

Corycella carinatus, DAkiN and Colefax, 1940, p. 110, figs. 182, a-c.

Remarks :

A few specimens of both sexes were found at a station on the leeward side of Oahu Island in winter.

The anterior body in the female is about 2.4 times as long as the abdomen. Abdominal segment is about twice as long as the furca. The dorsal margin of the abdominal segment, in lateral view, slopes rather smoothly, with the highest point just anterior of the middle of the segment.

The male is distinguished from those of $F$. gibbula and $F$. concinna by its 
eyes which are situated very close to each other.

Length: Female: $0.79 \mathrm{~mm}$.

Male : $0.87 \mathrm{~mm}$.

\section{Distribution:}

North Atlantic:

BRADY, 1883, as pellucidus.

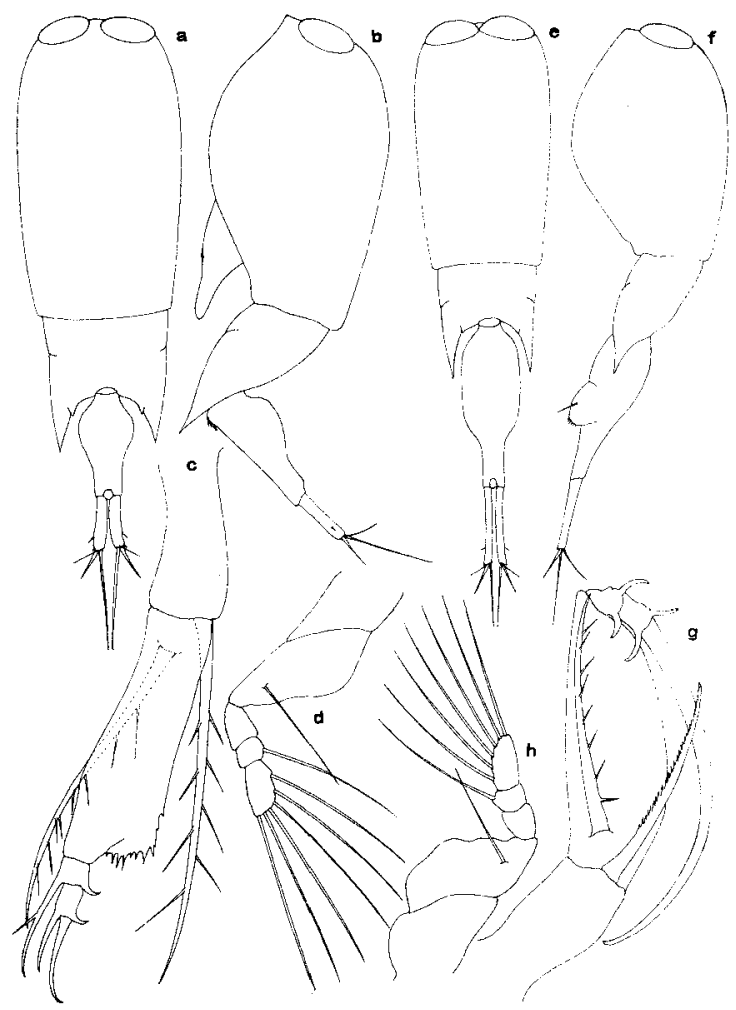

Fig. 28. Farranula carinata

$a$. Female, dorsal, $\times 64, b$. Female. lateral, $\times 64$, $c$. Female, 2nd antenna, $\times 270$, $d$. Female, 4 th foot, $\times 270$, e. Male, dorsal, $\times 64, f$. Male, lateral, $\times 64$, g. Male, 2nd antenna, $\times 270, h$. Male, 4 th foot, $\times 270$

WheEler, 1899, in the Gulf Stream off North America.

Wilson, 1932a, off Woods Hole.

Wilson, 1932b, Chesapeak Bay.

WILSON, 1942.

Gulf of Mexico :

GRICE, 1960. 
Mediterranean :

Thompson and A. Scott, 1903.

Rose, 1929.

Red Sea :

Thompson and A. ScotT, 1903.

Rose, 1929.

South Atlantic:

BRADY, 1883, as pellucidus.

Indo-Pacific :

BRADY, 1883, as pellucidus.

Thompson and A. Scott, 1903, Indian Ocean to Ceylon.

South Pacific :

FARran, 1936, Great Barrier Reef.

Dakin and Colefax, 1940, off New South Wales, Australia.

\section{Farranula concinna (DANA), 1848}

(Fig. 29)

Corycaeus concinnus DANA, p. 1848, p. 18.

Corycaeus concinnus, DANA, 1852-55, p. 1225, pl. 86, figs. 7, a, a', b.

Corycaeus concinnus, GIESBRECHT, 1891, p. 481.

Corycaeus concinnus, Giesbrecht, 1892, p. 675, p1. 51, figs. 21, 24.

Corycaeus concinnus, F. DAHL, 1894, p. 69.

Corycaeus concinnus, A. ScOTT, 1909, p. 246.

Corycella concinna, FARRAN, 1911, p. 286.

Corycaeus (Corycella) concinnus, M. DAHL, 1912, p. 121, pl. 15, figs. 5, 6, 11, 12, 23, 24, $33,34$.

Corycaeus concinnus, MORI, 1937, p. 138, pl. 77, figs. 5-12.

Corycella concinnus, DAKIN and ColEFAX, 1940, p. 110, fig. 181, a.

Farranula concinna, WILSON, 1942, p. 186, fig. 33.

Corycaeus (Corycella) concinnus, TANAKA, 1957a, p. 96, pl. 10, figs. 12-16.

Remarks :

The females of this species were more commonly found than any other species of Farranula around Oahu Island in both winter and summer, and they appeared north to $36^{\circ} \mathrm{N}$.

The anterior body of the female is about twice as long as the abdomen including the furca, and the abdominal segment in lateral view is nearly parallel to the ventral margin except for the posterior fifth. The specimen shown in Fig. 29 has only five setae on the 3rd segment of exopodite of the 4 th foot.

No male specimens which are reportedly smaller than $0.85 \mathrm{~mm}$ in total length and assignable to this species were found. (cf. male Farranula gibbula). Length: Female: 0.79-1.04 mm (average of 31 specimens, $0.91 \mathrm{~mm}$ ). 


\section{Distribution :}

North Atlantic:

Moore, 1949, Bermuda.

Indo-Pacific :

Giesbrecht, $1891,1892,0^{\circ}, 108^{\circ} \mathrm{W} ; 9^{\circ} \mathrm{N}, 119^{\circ} \mathrm{W}$.

Thompson and A. Scott, 1903, Suez to Ceylon.

BeDOT, 1909, Malay Archipelago.

A. SCOTT, 1909.

Farran, 1911, Christmas I. in Indian Ocean.

M. DAHL, 1912.

MoRI, 1942, Palau Is., western Caroline.

WILSON, 1942.

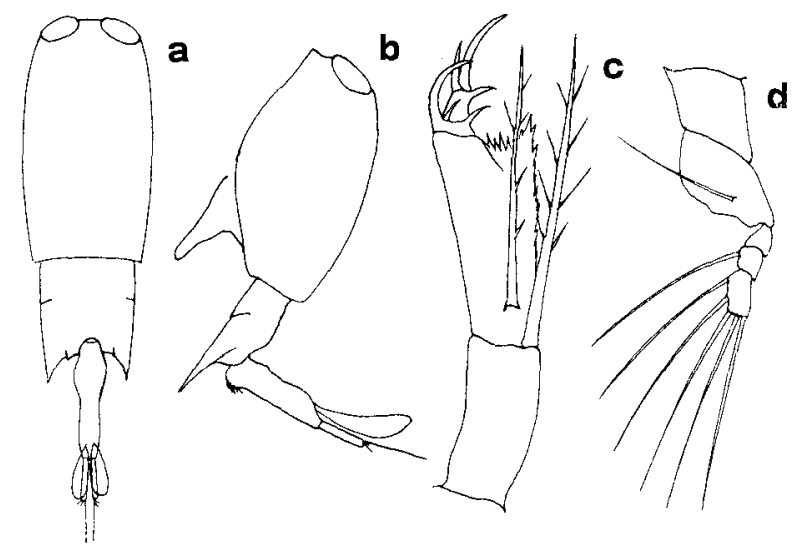

Fig. 29. Farranula concinna

$a$. Female, dorsal, $\times 53, \quad b$. Female, lateral, $\times 53, c$. Female, 2nd antenna, $\times 220, d$. Female, 4th foot, $\times 220$

Tsuruta and Chiba, 1954, Mid-Pacific.

Chiba and Tsuruta, 1955, west of Sunda Is.

Chiba et al. 1957, northern Indian Ocean.

Tsuruta et al. 1957, eastern Indian Ocean.

East China Sea :

Mori, 1937.

South Pacific:

Dana, $1848,1852-55,15^{\circ} 35^{\prime} \mathrm{S}, 138^{\circ} 30^{\prime} \mathrm{W}$, Tongatabu.

FARran, 1936, Great Barrier Reef.

Dakin and Colefax, 1940, off New South Wales, Australia. North Pacific:

Mori, 1937, off Japan. 
Maeda, 1956, Tsugaru Straits.

TANAKA, 1957 a, off Japan.

YAMAZI, 1958, Tanabe Bay, Wakayama.

OLson, (MS.), off west coast of North America.

\section{LITERATURE CITED}

ANraku, Masateru, 1952. Plankton copepods collected by R. S. Yushiwo Maru in Pacific waters to the east of northern Japan during her cruise in November 1948. Bull. Fac. Fish., Hokkaido Univ. 3 (1), 31-39.

1953. Seasonal distribution of pelagic copepods at Oshoro Bay, west coast of Hokkaido. Ibid. 3 (2), 187-192.

1954. Copepods collected on the whaling grounds off northern Japan and around Bonin Islands. Ibid. 5 (1), 1-8.

Bedot, Maurice, 1909. Sur la Faune de l'Archipel Malais (Résumé). Revue Suise de Zoologie. Annales de la Société Zoologique Suisse et du Muséum d'Historie Naturelle de Genève. Tome 17, 143-169.

BRADY, George Stewardson, 1883. Report on the Copepoda collected by H. M. S. "Challenger." during the years 1873-76. Rep. Sci. Res. Voyage H. M. S. "Challenger." Zool. 8, pt. 23, 1-142, 55 pls.

Breemen, P. J. van, 1908. Copepoden. Nordisches Plankton. Zool. Teil. 4 Bd. Entomostraca VIII, 1-264, 251 figs.

Candeias, Alberto, 1926. Première liste des copépodes des côtes du Portugal. Bulletin de la Société Portugaise des Sciences Naturelles. Tome 10 (3), 23-58, pls. II, III. (Two Pl. II are bound. instead of Pl. II and Pl. III)

Crrmba, Takuo, 1949. On the distribution of the plankton in the eastern China Sea and Yellow Sea. 1. Plankton composition in spring. Jour. Shimonoseki Coll. Fish. 1 (1), 57-63. 1954. Some observations on the morphological characteristics especially on the reproductive organ of Copepoda, Calanus darwinii. Ibid. 3 (3), 235-253.

1956. Studies on the development and the systematics of copepods. Ibid. 6 (1), $1-90$.

Chiba, Takuo, Takerow Satow, Arao Turuta, Osamu Hrano and Shoji Tagawa, 1957. Oceanographical and planktological studies of the tuna-fishing grounds in the middle part of the northern Indian Ocean. Ibid. 6 (3), 291-313.

Chiba, Takuo and Arao Tsuruta, 1951. On the distribution of the plankton in the eastern China Sea and the Yellow Sea. III. Observation on the plankton in the Straits of Tsushima in summer of 1950. Bull. Jap. Soc. Sci. Fish. 16 (12), 96-100. and 1955. On the plankton in the western sea regions of Sunda Islands. Jour. Shimonoseki Coll. Fish. 4 (1), 83-94.

Chiba, Takuo, Arao Tsuruta and Hiroshi MAedA, 1955. Report on zooplankton samples hauled by larva-net during the cruise of Bikini Expedition, with special reference to copepods. Ibid. 5 (3), 189-213.

DAHL, F. 1894. Ueber die horizontale und verticale Verbreitung der Copepoden im Ocean. Verhand. d. deutsch. Zool. Gesellsch. auf der vierten Jahresversammlung zu München, April 1894, 61-80, Fig. 104.

DAHL, Maria, 1912. Die Copepoden der Plankton-Expedition. I. Corycaeinen mit Berücksichtigung aller bekannten Arten. Ergebn. d. Plankton-Exped. d. Humboldt-Stift. Bd. 2, G, f, 1, 1-134, Taf. $1-15$.

DAkIN, Wiliam J. and Alan N. ColefAx, 1940. The plankton of the Australian coastal waters off New South Wales. Pt. 1. Publ. Univ. Sydney, Dept. Zool. Monogr. No. 1, 1-215, textfigs. 1-303, pls. 1-4. 
TANAKA, Otohiko, 1957a. On the Copepoda of the Family Corycaeidae in Japanese waters. Jour. Fac. Agr., Kyushu Univ. 11 (1), 77-97, pls. 3-10.

1957b. Zooplankton in the Tsushima Warm Current. I. Freeswimming Copepoda in Japan Sea. pp. 1-32, pls. 1-5. (Mimeogr.) published by Fisheries Agency of Japan. (in Japanese)

Thompson, Isaac C. 188. Copepoda of Madeira and the Canary Islands, with descriptions of new genera and species. Jour. Linn. Soc. Lond., Zool. 20, 145-156, pls. 10-13.

Thompson, Isaac C. and Andrew ScOTt, 1903. Report on the Copepoda collected by Professor Herdman, at Ceylon, in 1902. Report to the Government of Ceylon on the Pearl Oyster Fisheries of the Gulf of Manaar. With supplementary Reports upon the Marine Biology of Ceylon. Part I, 7, 227-307, pls. 1-20.

TokIOKA, Takasi and Isamu YAMAzI, 1950. Studies on pearl oyster culture bed. I. Qualitative distribution of plankton in Ago Bay. Contrib. Physiol. Ecol. Kyoto Univ., 71, 19-61. (In Japanese)

TokiokA, Takashi, Yamazi and Shin-ichiro Fuse, 1951. Studies on pearl oyster culture bed. V. Influence of Fukaya Passage on Funakoshiura area. Ibid. 73, 1-31. (In Japanese)

Tsuruta, Arao and Takuo CHIBA, 1954. On the plankton at the fishing ground of tuna in the Mid-Pacific Ocean (1953). Jour. Shimonoseki Coll. Fish. 3 (3), 247-253.

Tsuruta, Arao, Takerow, Satow, Kazuhiko HAYAMA and Takuo CHIBA, 1957. Oceanographical and planktological studies of tuna fishing ground in the eastern part of the Indian Ocean. Ibid. 7 (1) (The 10th Anniversary), 1-17.

Wheeler, William Morton, 1901. The free-swimming copepods of the Woods Hole region. Bull. U. S. Fish Commission Vol. 19 for 1889, 157-192, 30 figs.

WILson, Charles Branch, 1932a. The copepods of the Woods Hole region, Massachusetts. U. S. Nat. Mus. Bull. 158, 1-635, pls. 1-41.

1932b. The copepod crustaceans of Chesapeak Bay. Proc. U.S. Nat. Mus. 80, Art. $15,1-54$, pls. $1-5$.

1942. The copepods of the plankton gathered during the last cruise of the Carnegie. Sci. Res. of Cruise VII of the Carnegie during 1928-1929 under the command of Captain J. P. Ault., Biol. 1, 1-237, pls. 1-136.

1950. Copepods gathered by the United States Fisheries Steamer "Albatross" from 1887 to 1909 , chiefly in the Pacific Ocean. Contributions to the biology of the Philippines Archipelago and adjacent regions. U. S. Nat. Mus. Bull. 100, Vol. 14, Pt. 4, 141-441, pls. 2-36. WOLFENDEN, R. Norris, 1911. Die marinen Copepoden der deutschen Südpolar-Expedition 19011903. II. Die pelagischen Copepoden der Westwinddrift und des sudlichen Eismeers. Mit Beschreibung meherer neuer Arten aus dem atlantischen Ozean. Deut. Sudpolar-Exped. 19011903., Bd. 12, Zool., Bd. 4. Heft 4, 181-380, Taf. 22-41, Textfig. 1-82.

YAMAZI, Isamu, 1952a. Plankton investigation in inlet waters along the coast of Japan, V. The plankton of Hiroshima Bay in the Seto-Naikai (Inland Sea). Publ. Seto Mar. Biol. Lab., 2 (2), 319-330.

1952b. Plankton investigation in inlet water along the coast of Japan. VI. The plankton of Nanao Bay. Spec. Pap. Third Anniversary Japan Sea Reg. Fish. Res. Lab., 309-319. 1954. Plankton investigation in inlet waters along the coast of Japan. XIII. The plankton of Obama Bay on the Japan Sea coast. Publ. Seto Mar. Biol. Lab., 4 (1), 103-114. 1958. Preliminary check-list of plankton organisms found in Tanabe Bay and its environs. Ibid, 7 (1), 111-163. 
Table 1. Occurrence of Corycceeus and Farranula in Hawaiian waters in January and August 1956 , and from Hawaii north to $50^{\circ} \mathrm{N}$. along $157^{\circ} 50 \mathrm{~W}$. in August 1955 .

\begin{tabular}{|c|c|c|c|c|c|c|c|c|c|c|c|c|c|c|c|c|c|c|c|c|c|c|c|c|}
\hline & Vessel and cruise number & JRM-29 & $\mathrm{JRM}-29$ & JRM-29 & JRM-29 & IRM-29 & JRM-29 & HMS-35 & HMS- -35 & HMS-35 & HMS -35 & HMS-35 & MAKUA-24 & \begin{tabular}{|l|} 
MAKUA-24 \\
\end{tabular} & HMS-30 & HMS-30 & HMS-30 & HMS-30 & HMS-30 & HMS- 30 & HMS- -30 & HMS-30 & HMS-30 & HMS-30 \\
\hline & Station & 1 & 3 & 5 & 16 & 18 & 20 & 3 & 10 & 15 & 31 & 35 & A & B & 112 & 109 & 106 & 103 & 100 & 97 & 94 & 90 & 87 & 84 \\
\hline & Latitudes & $21^{\circ} 25^{\prime} \mathrm{N}$ & $21^{\circ} 28^{\prime} \mathrm{N}$ & $21^{\circ} 25^{\prime} \mathrm{N}$. & $22^{\circ} 16^{\prime} \mathrm{N}$ & $21^{\circ} 57^{\prime} \mathrm{N}$ & ${ }_{21} 1^{\circ} 6^{\prime} \mathrm{N}$. & $21^{\circ} 04^{4} \mathrm{~N}$ & $21^{\circ} 24^{\prime} \mathrm{N}$ & $21^{\circ} 25^{\prime} \mathrm{N}$ & $22^{\circ} 16^{\prime} \mathrm{N}$ & $21^{\circ} 40 \mathrm{~N}$ & \multirow{2}{*}{$\begin{array}{l}\text { Southwest } \\
\text { coast of } \\
\text { Oahu I. }\end{array}$} & \multirow{2}{*}{$\begin{array}{c}\text { Southwest } \\
\text { coast of } \\
\text { Oahu I. }\end{array}$} & $23^{\circ} 56^{\prime} \mathrm{N}$ & $26^{\circ} 58^{\prime} \mathrm{N}$ & $29^{\circ} 54^{4} \mathrm{~N}$ & $32^{\circ} 577^{\mathrm{N}} \mathrm{N}$ & $35^{\circ} 58^{\prime} \mathrm{N}$. & $38^{\circ} 58^{\prime} \mathrm{N}$ & $41^{\circ} 57^{\prime} \mathrm{N}$ & $44^{\circ} 58^{\prime} \mathrm{N}$. & $48^{\circ} 06^{\prime} \mathrm{N}$. & $49^{\circ} 48^{\prime} \mathrm{N}$ \\
\hline & Longitudes & $158^{\circ} 16^{\prime} \mathrm{w}$ & $158^{\circ} 36^{\prime} \mathrm{w}$. & $158^{\circ} 56^{\prime} \mathrm{w}$. & $157^{\circ} 45^{\prime} \mathrm{w}$. & $157^{\circ} 47^{\prime}$ w. & $15^{\circ} 46^{\circ} \mathrm{w}$ & $158^{\circ} 04^{\prime} \mathrm{w}$. & $158^{\circ} 16^{\prime} \mathrm{w}$. & $159^{\circ} 06^{\prime} \mathrm{W}$ & $157^{\circ} 48^{\prime} \mathrm{w}$. & $157^{\circ} 48^{\prime} \mathrm{w}$. & & & $157^{\circ} 31^{\prime} \mathrm{w}$ & $157^{\circ} 28^{\prime} \mathrm{w}$. & $157^{\circ} 29^{\prime} \mathrm{w}$. & $157^{\circ} 29^{\prime} \mathrm{w}$. & $157^{\circ} 30^{\circ} \mathrm{w}$. & $157^{\circ} 30 \mathrm{w}$ & $157^{\circ} 23^{\prime} \mathrm{w}$ & $157^{\circ} 26^{\prime}$ w. & $157^{\circ} 24^{4} \mathrm{~W}$. & $159^{\circ} 42^{2} \mathrm{w}$. \\
\hline & Date & Jan, 5 & $\begin{array}{l}\operatorname{Jann}_{1956} 5 \\
1956\end{array}$ & 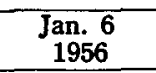 & 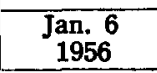 & 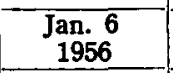 & 志, 6 & $\begin{array}{l}\text { Augg. } \\
1956\end{array}$ & $\begin{array}{l}\text { Aug } 2 \\
1956\end{array}$ & $\begin{array}{l}\mathrm{A}_{1956,3} \\
1956\end{array}$ & $\begin{array}{l}\text { Aug. } 4-5 \\
\text { 1956 }\end{array}$ & \begin{tabular}{|l} 
Aug, 5 \\
19656
\end{tabular} & $\begin{array}{l}\text { Dec. 21 } \\
1956\end{array}$ & $\begin{array}{l}\text { Dec, 21 } \\
1956\end{array}$ & $\begin{array}{l}\text { Aux } 227 \\
\text { 1955 }\end{array}$ & $\begin{array}{l}\text { Aug. } 26 \\
1955\end{array}$ & $\begin{array}{l}\text { Auy, 25 } \\
1955\end{array}$ & $\begin{array}{l}\text { Aug, 24 } \\
1955\end{array}$ & $\begin{array}{l}\text { Aug, } 23 \\
\text { 1955 }\end{array}$ & $\begin{array}{l}\text { Aug, 23 } \\
1995 \\
195\end{array}$ & $\begin{array}{ll}\text { Aug, 22 } \\
\text { A995 }\end{array}$ & $\begin{array}{l}\text { Aug, 21 } \\
\text { 1995 }\end{array}$ & $\begin{array}{l}\text { Aug, } 19- \\
1955\end{array}$ & $\begin{array}{l}\text { Aug, 18 } \\
\text { A995 } \\
\end{array}$ \\
\hline & Time (Zone time) & $2009-2037$ & $2244-2306$ & $0125-0147$ & 1533-1557 & 1811-1833 & $2053-2115$ & $0132-0203$ & $2007-2036$ & 1010-1041 & $2354-026$ & 0930-1000 & 1045-1115 & 1412-1442 & $2244-2254$ & $2257-2308$ & $2303-2313$ & 2234-2258 & $2345-0000$ & $0110-0121$ & 0222-0232 & 0400-0414 & $2328-2340$ & $2315-2327$ \\
\hline & Temperature $\left({ }^{\circ} \mathrm{C}\right)$ in surface water & 24.3 & 24.3 & 23.3 & 24.7 & 23.7 & 23.9 & 26.1 & 25.8 & 25.6 & 24.7 & 24.8 & 25.6 & 25.8 & 24.5 & 24.5 & 24.5 & 24.4 & 24.5 & 23.7 & 20.6 & 16.4 & 12.4 & 111.1 \\
\hline & Salinity $(\%)$ in surface water & 35.01 & 35.10 & 35.12 & 35.07 & 33.16 & 35.05 & 34.65 & 34.61 & 34.78 & 34.74 & 34.83 & 34.92 & 34.94 & 35.04 & 35.34 & 35.50 & 35.08 & 34.51 & 34.11 & 33.86 & 33.09 & 32.61 & 32.54 \\
\hline & Depth of haul $(\mathrm{m})$ & $0-60$ & $0-60$ & $0-60$ & $0-60$ & $0-60$ & $0-60$ & $0-43$ & $0-45$ & $0-45$ & $0-52$ & 0.43 & Surface & Surface & $0-49$ & $0-52$ & $0-59$ & $0-40$ & $0-33$ & $0-34$ & $0-27$ & $0-29$ & $0-26$ & $0-33$ \\
\hline & Corycaeus (Corycaeus) speciosus, female & 20 & 130 & - & 17 & 6 & 38 & 51 & 10 & 49 & 43 & 19 & - & - & 18 & - & 17 & 4 & - & - & - & - & - & - \\
\hline & male & & - & - & 4 & - & - & 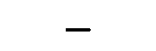 & - & 28 & 21 & 39 & 10 & 10 & 9 & 7 & - & 1 & - & - & - & - & - & - \\
\hline & young femal & - & - & - & - & - & 5 & - & - & 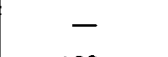 & - & 19 & - & - & - & - & - & - & - & - & - & - & - & - \\
\hline & $\begin{array}{l}\text { Corycaeus (Corycaeus) crassiusculus, female } \\
\text { male }\end{array}$ & 5 & 33 & 19 & 8 & 22 & 54 & 100 & 42 & 160 & 21 & 39 & 53 & $\bar{m}$ & 37 & 7 & - & - & - & - & - & - & - & - \\
\hline & Corycaeus (Coryccaus) vitreus, male male & 5 & 25 & $-\overline{13}$ & - & - & 5 & 100 & 10 & 130 & 64 & 19 & 64 & 20 & - & - & - & - & $\overline{-}$ & - & - & - & - & $\overline{-}$ \\
\hline & 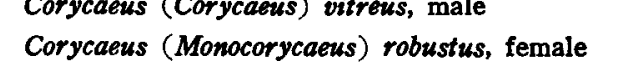 & $\begin{array}{r}10 \\
5\end{array}$ & 25 & - & $\overline{-}$ & $\overline{-}$ & -5 & (26 & ${ }_{10}^{21}$ & ${ }_{82}^{44}$ & ${ }_{43}^{21}$ & ${ }^{19}$ & ${ }_{53}^{32}$ & $=$ & ${ }_{37}^{28}$ & 7 & - & - & $=$ & - & $=$ & - & - & 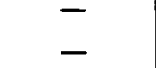 \\
\hline & male & & - & - & - & - & & 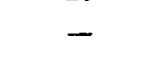 & 10 & 6 & - & 19 & - & - & - & - & - & - & - & - & - & - & - & - \\
\hline$g$ & Coryccaus (Agetus) typicus, female & - & - & - & 45 & 45 & 85 & - & 21 & 11 & 20 & - & - & - & - & 7 & - & - & - & - & - & - & - & - \\
\hline छ & $\begin{array}{l}\text { maryccaus (Agetus) faccus, female } \\
\text { Ceme }\end{array}$ & $-\overline{41}$ & $\overline{58}$ & $\overline{19}$ & $\overline{21}$ & - & 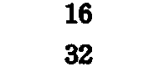 & - & $\overline{21}$ & $\overline{2}$ & - & 19 & - & $\overline{10}$ & - & - & - & z & - & $=$ & - & - & $\overline{-}$ & - \\
\hline 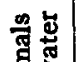 & male & 36 & 66 & 38 & 50 & 39 & 16 & - & - & - & 64 & - & - & 10 & 18 & - & - & - & - & - & - & - & - & $\overline{-}$ \\
\hline 是 & Corycaeus (Agetus) limbatus, male & -5 & - & $\overline{13}$ & $\overline{10}$ & - & 43 & - & - & - & - & - & - & - & - & - & - & - & - & - & - & - & - & - \\
\hline 等 & Corycceus (Urocorycceuss) longistylis, female & ${ }_{-}^{5}$ & $\overline{-}$ & 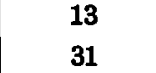 & 12 & ${ }_{6}^{17}$ & ${ }_{27}^{43}$ & ${ }_{-}^{26}$ & ${ }_{10}^{21}$ & - & - & $\overline{19}$ & - & $\overline{20}_{20}$ & 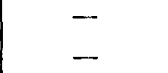 & -7 & $\bar{z}$ & - & - & $\bar{z}$ & $\overline{-}$ & $=$ & - & - \\
\hline 然客 & Coryccaeus (Urocorycaeeus) lautus, female & 20 & 91 & - & 25 & 11 & 5 & 52 & 32 & 44 & 110 & 19 & 10 & 41 & 18 & 22 & 17 & 6 & - & - & - & - & - & - \\
\hline 悬営 & $c^{\prime}$ & 10 & 41 & - & 42 & 11 & - & 91 & 32 & 39 & 43 & 58 & 53 & 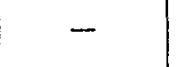 & - & - & 33 & 3 & - & - & - & - & - & - \\
\hline 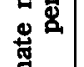 & vcaeus) asiaticus, male & - & - & - & - & - & 5 & 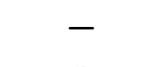 & - & - & - & - & 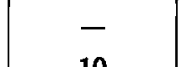 & - & $\overline{0}$ & - & - & - & - & - & - & - & - & - \\
\hline & Corycaeus $(0$, & 5 & $\overline{-}$ & - & $\overline{-}$ & - & ${ }^{5}$ & - & - & ${ }_{6}^{16}$ & - & 19 & 10 & - & 9 & - & - & - & - & - & - & - & - & - \\
\hline & 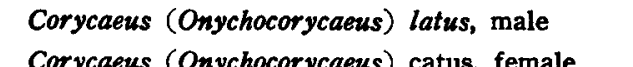 & - & - & $=$ & 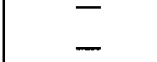 & - & ${ }_{21}^{11}$ & $\overline{13}$ & - & ${ }^{6}$ & $\overline{21}$ & - & 10 & $\begin{array}{l}- \\
-\end{array}$ & 9 & - & -8 & - & - & $\overline{-}$ & $=$ & - & - & - \\
\hline$\frac{9}{4}$ & 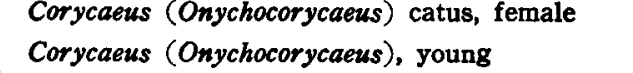 & 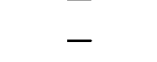 & 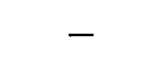 & 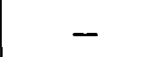 & 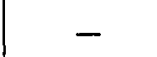 & 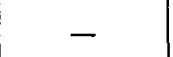 & $\begin{array}{l}21 \\
11\end{array}$ & 10 & - & 11 & 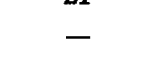 & - & 21 & - & $z$ & 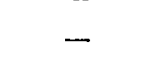 & - & - & - & 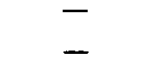 & 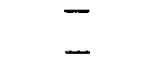 & - & - & - \\
\hline & Corycceeus, young & 66 & - & - & 8 & - & 11 & 39 & 32 & 28 & 43 & 39 & - & - & 9 & - & - & 1 & - & - & - & - & - & - \\
\hline & Farranula gibbula, female & 5 & - & - & 8 & 6 & 16 & - & 21 & 11 & - & & 32 & 41 & 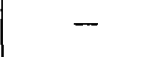 & 7 & - & - & - & - & - & - & - & - \\
\hline & fomp & 5 & - & - & - & 6 & 5 & - & - & - & - & 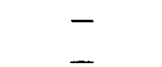 & - & 10 & $=$ & - & - & $=$ & $\overline{-}$ & - & - & - & - & $\bar{z}$ \\
\hline & $\begin{array}{l}\text { Farranula carinata, female } \\
\text { male }\end{array}$ & - & z & $\begin{array}{c}- \\
-\end{array}$ & $\begin{array}{c}- \\
-\end{array}$ & $\overline{-}$ & $\overline{-}$ & - & - & z & - & z & - & 10 & $\overline{-}$ & - & $\bar{z}$ & - & $\bar{z}$ & $=$ & z & $\overline{-}$ & - & $\overline{-}$ \\
\hline & Farranula concinna, female & - & 8 & - & 8 & 6 & 32 & - & - & 6 & - & - & 10 & 10 & 110 & 37 & 17 & 14 & 1 & - & - & - & - & - \\
\hline & Total & 238 & 494 & 133 & 248 & 220 & 461 & 537 & 293 & 699 & 515 & 336 & 358 & 182 & 302 & 108 & 92 & 29 & 1 & 0 & 0 & 0 & 0 & 0 \\
\hline
\end{tabular}

